Saffet Erdoğan
Harran University, serdogan@harran.edu.tr, Şanlıurfa-Turkey Recep Aslan

Afyon Kocatepe University, raslan@aku.edu.tr, Afyonkarahisar-Turkey

\begin{tabular}{l|l|l|l}
\hline \hline DOI & \multicolumn{2}{|c}{ http://dx.doi.org/10.12739/NWSA.2021.16.1.4C0240 } \\
\hline ORCID ID & $0000-0003-2846-853 \mathrm{X}$ & $0000-0002-7541-0405$ \\
\hline \multicolumn{2}{c}{ CORRESPONDING AUTHOR } & Saffet Erdoğan \\
\hline \hline
\end{tabular}

SÜRDÜRÜLEBİLİ KALKINMA İÇİN EŞİTSİLIKKLERİN AZALTILMASI: MEKÂNSAL ADALET

öz KAVRAMI IŞIĞINDA BİR CBS UYGULAMASI

Çalışma Türkiye'deki işsizlik, satın alma gücü paritesi ve boşanma verileri üzerinden mekansal eşitsizliği incelemektedir. BM Sürdürülebilir Kalkınma Hedefleri doğrultusunda incelenen bu veriler, adalet kavramının mekânsal boyutunu ifade eden "mekânsal adalet" kapsamında mekânsal istatistiksel yöntemler kullanılarak tartışılmaya çalışılmıştır. Çalışma sonuçları göstermiştir ki kişi başı satın alma paritesi cinsinden geliri yüksek yerlerde hem işsizlik hem de boşanma değerleri oldukça yüksektir. Bu bulgu, mekânsal adaletsizliğin ekonomik ve sosyolojik olarak beraberinde sorunlar getirdiğine işaret etmekte ve sosyoloji gibi disiplinler tarafından sebep sonuç ilişkisinin daha detaylı araştırılmasına ihtiyaç duyulmaktadır. İkinci olarak, kişi başı satın alma paritesi cinsinden geliri yüksek yerlerdeki mahallelerdeki yüksek işsizlik ve boşanma değerleri, ekonomik, toplumsal ve sosyolojik değerlerin ayrışmalarının birbirini desteklediğidir. Bu mahallelerin yer aldığı illerde ülke genelindeki farklılaşmanın çok üstünde bir toplumsal ve ekonomik farklılık ve yarılma olduğu görülmüştür. Her iki durum da mekansal adaletsizlikle yüzleşilmesi gereğini ortaya koymaktadır. Umuyoruz ki çalışmada ele alınan bulgular, karar vericilere eşitsizlikle mücadelede yardımcı olacak, araştırmacılara da çözüm amaçlı çalışmalarında referans olacaktır.

Anahtar Kelimeler: Mekansal Adalet, Coğrafi Bilgi Sistemleri, Mekansal Oto Korelasyon, İşsizlik, Satın Alma Paritesi

\title{
REDUCING INEQUALITIES FOR SUSTAINABLE DEVELOPMENT: A GIS APPLICATION IN THE LIGHT OF THE CONCEPT OF SPATIAL JUSTICE
}

\section{ABSTRACT}

The study, examines the inequality in the light of the concept of spatial justice by using unemployment, divorce and purchase power parity data in Turkey. In line with the United Nations Sustainable Development Goals, within the scope of "spatial justice", which expresses the spatial dimension of justice, the distribution and comparison of unemployment, divorce and purchasing power parity data has been analysed using spatial statistical methods. Results showed that in places with high income per capita in terms of purchasing parity, both unemployment and divorce values are quite high. This finding points out that spatial injustice brings economic and sociological problems with it, and a more detailed investigation of the cause and effect relationship is required by disciplines such as sociology. Secondly, high unemployment and divorce values in neighborhoods with high income in terms of per capita purchasing parity is that the differentiation of economic, social and sociological values support each other. It has been observed that there is a social and economic difference and split in the provinces where these neighborhoods are located, far above the differentiation across the country. Both situations reveal the need to face spatial injustice. We hope that the findings and inferences discussed in the study will assist decision makers in combating inequality and will be a reference for researchers in their work to solve this problem.

Keywords: Spatial Justice, Geographic Information Systems, Spatial Auto Correlation, Unemployment, Purchasing Parity

How to Cite:

Erdoğan, S. ve Aslan, R., (2021). Sürdürülebilir Kalkınma İçin Eşitsizliklerin Azaltılması: Mekânsal Adalet Kavramı Işı̆̆ında Bir CBS Uygulaması, Humanities Sciences (NWSAHS), 16(1):1-23, DOI: 10.12739/NWSA.2021.16.1.4C0240. 


\section{GİRIŞ (INTRODUCTION)}

Insan, olaylarda edindiği bilgilerde hissettiği manaları kavramlarla tanımlayıp ifade edebilmiştir. Hisleri anlayış, yaşayış ve anlatış, kavramlarla ifade edilen manalar üzerinden gerçekleşmektedir. Bu nedenle, bir konuda aynı hissiyatı yakalayabilmek için, manaları işaret eden kavramları güncellenmiş ve evrensel özellikleriyle somut olarak anlamak, tanımlamak ve zihnimizde doğru olarak somutlaştırmak gerekmektedir. Zaman içerisinde değişen şey manalar olmayıp, manalarla ilgili kavramlar ve kavramların tanımlanışlarıdır. Bir manayı anlamak ve ortak bir hissiyat oluşturabilmek için kavramlarla kastedilen duygu ve bilincin varlığı elzemdir. Kavramlar doğru tanımlanmadığında veya tanımları farklı olduğunda, bilinç ve hissediş karışıklıkları oluşmaktadır. Bu durum, ortak platformlar üzerinde geliştirilecek paylaşım ve tartışmaların doğru kulvarda ilerlemesini engelleyecektir $[17]$.

Yüksek ve sürdürülebilir bir medeniyet inşa etmiş toplumumuzun, sürdürülebilirlik, uygarlık, adalet, ümran, birlikte yaşama, şeffaflık gibi kavramları yansıtması ve yaşatması rasyonel bir beklentidir. Bu anlamda, günümüzün teknoloji seviyesi hayatta yüksek bir iyileşme ve gelişme beklentisi oluşturmasına rağmen, her yerde karşımıza insan eliyle kirlenme ve bozulma çıkmaktadır. Hava, su, toprak, ışık, ses, şehir ve yerleşim alanları, toplumsal yaşantının üzerine bina edildiği kavramlar, ticaret, ekonomi, davranış ve alışkanlıklarda kirlenme yaygındır. Bunun sorumlusu olarak karşımıza insan çıkmakta; insan, bozulan algısıyla doğaya, yaşadığı şehir ve topluma bu algısını kazımakta, bu algı bozulması sosyal anlayışa doğrudan etki etmektedir. Günümüzde sanayi, ulaşım, sağlık, ekonomi ve eğitim gibi nedenlerle şehirler cazibe merkezleri olurken, hızlı ve plansız göçlerle sosyokültürel ve ekonomik yarılmalar artmış, problemler devasa hale gelmiştir. Bu süreçlerin getirdiği kontrolsüz ve plansız kentleşme ile paralel olarak farklılaşan sosyoekonomik, kültürel demografik yapılar, bazı kaynaklar ve değerlerin yok olma seviyesine geldiğini göstermiş ve "sürdürülebilirlik" kavramını entelektüel ve sosyal değerler alanında da gündemimize sokmuştur.

Bu bakışla, makalede Birleşmiş Milletler Sürdürülebilir Kalkınma Hedeflerine değinilerek, temel sosyal ve ekonomik değerlerin ancak, adalet kavramının mekân boyutunu ifade eden "mekânsal adalet" kapsamında anlaşılabileceği ve yaşanabileceği hususu üzerinde durulmuştur. Sürdürülebilirlik ile ilgili problemlerin mekansal adalet ile ortaya çıkarılabilmesi uygulaması, ülkemiz örneğinde bazı değişkenlerle, coğrafi bilgi sistemleri ve mekânsal istatistiksel yöntemler kullanılarak ortaya konulmaya çalışılmıştır. Medeniyetimizin ontolojik anlayışına uygun olarak, evrensel genel doğrular çerçevesinde "varlık" ve "mülkiyet" kavramlarından yola çıkarak önce, "adalet" ve "eşitlik", daha sonra günümüzde sıklıkla konuşulan "mekânsal adalet" kavramı farklı boyutlardan irdelenerek tartışılmıştır. Eşitsizliklerin çok kriterli ve çok katmanlı oluşu sebebiyle, eğitim, sağlık, gelir dağılımı, yoksulluk ve istihdam gibi başlıkları bir çalışmada topyekûn ortaya koymak zordur. Bu anlamda, Sürdürülebilir Kalkınma Amacı-10 (SKA 10) hedefleri kapsamında Türkiye için önerilen bölgesel, sektörel ve kırılgan kesimler bazında eşitsizliklerin azaltılması, gelir dağılımının iyileştirilmesi ve fırsat eşitliğinin artırılması önerilerini gerçekleyebilmek amacıyla; işsizlik, kişi başına gelir cinsinden satın alma paritesi (GDP-PPP) ve boşanma kriterleri örneklerinde incelemeler yapılmıştır. Bunun için ilçe seviyesinin altına inilerek, posta kodu 5 seviyesinde coğrafi sınırlar kullanılarak coğrafi bilgi sistemleri (CBS) ve mekânsal kümeleme yöntemleri kullanılmıştır. Çalışma, mekânsal adalet kavramının doğru algıyla tanımlanması ve ülkemizdeki mekânsal adalete 
katkısı adına da önem arz etmektedir. Türkiye için, ülke çapında ve mahalle düzeyinde bu kapsamda bir veri setinin ilk kez kullanıldığı ve çalışmanın ülke profilini bu detayda ortaya koyan ilk örnek araştırma olması da ayrıca önem teşkil etmektedir.

\section{2. ÇALIŞMANIN ÖNEMI (RESEARCH SIGNIFICANCE)}

Çalışma, ülkemizde yeni bir konu olan mekânsal adalet kavramının doğru anlaşılmasına katkıda bulunma adına, kavramın dikey üst manalarından başlayarak uygulamada doğru konumlanmasını sağlama adına önem arz etmektedir. Adalet kavramının iç ve dış unsurlarının olduğunu, her iki unsurun da önemsenmesi gerektiğini işaret ederek, boşanma, işsizlik ve de satın alma paritesi değerleri üzerinden bir çalışma yapılmıştır. Kişi başı satın alma paritesi değeri üzerinden ifade etmek gerekirse; bu gösterge rakamsal açıdan yüksek gibi görülse de çalışma ile bunun yurt içindeki dağılımı da dikkate alınıp ortaya konulduğunda, sonuçlar durumun farklı olduğunu göstermektedir. Yine çalışma, posta kodu 5 adı verilen, ilçe sınırlarından daha düşük ölçekte olan ve büyük şehir merkezlerinde mahalle sınırları seviyelerini yakalayabilen bir ölçekte veri seti kullanılarak gerçekleştirilmiştir. Bu detayda ve ölçekte veri ile literatürde karşılaşılmamış olup, çalışmanın bundan sonraki birçok çalışmaya referans olacağı ön görülmektedir.

\section{VARLIK ALGISI, MÜLKİYET, ADALET VE MEKÂNSAL BOYUT (PERCEPTION OF EXISTANCE, OWNERSHIP, JUSTICE AND SPATIAL JUSTICE)}

Fenomenlerin (yaratılmışların) gerçekliği ve hakikatle ilişkisi bağlamında varlık, Allah'ın emrinin bir sureti olarak zaman ve mekân şartları ile yaratılmıştır. Bu var oluş süreci içerisinde insanın var olma serüveni de önce bedensel sonra da entelektüel olgunlaşma içeren bir projeksiyonla başlamıştır. Özellikle entelektüel gelişim sürecinin başlangıç noktası olan Hazreti Âdem'den itibaren, varlık algısıyla ilgili ilk ikilem/düalite de başlamıştır. Bu düalite incelendiğinde, "varlık" algısının yasal ve yasal olmayan iki durumu söz konusudur. Bu algının yasal olmayan hali, kişinin varlığını Allah'ın dışında vehmettiği bir mekânda müstakil olarak var ve muhtar sanmasıdır. Oluşturduğu bu idrak ile bir takdim oluşturması, hayat tarzını ve yaşantısını bu doğrultuda anlaması, yaşaması ve davranması bu algının beklenen davranışsal devamıdır. Yasal olmayan bu algısıyla kişi gerçek var ve muhtar olan manaya (Allah'a) ortak olarak "ben de varım ve muhtarım" diyerek ikiliği/düaliteyi yani İslam literatüründeki "şirk" algısını oluşturmuştur. Bu algı, dünya yaşantısında doğuştan mevcuttur ve çok kuvvetlidir. Bu algının öncesi yasal varlık algısıdır ki işletim sistemi o algı ile çalışan insana, literatürde "kalb-i selim" denilmiştir (26, 89). Yasal olan bu "varlık" algısının, insanın hem dünya yaşantısı hem de sonsuz hayatı için önemi ve etkisi büyüktür [16]. Yaratıcıyı anlayabilmek, varlığı doğru anlamlandırarak buna uygun davranışlarda bulunabilmek için, "müstakilen varım ve muhtarım" algısı ve iddiası olmaksızın "varlık" algısı temel şarttır [16, 18 ve 53]. Bu bakışla, insanlık tarihi aslında "Gerçek Var"ı hakkıyla tanıyabilme ve tanıdığı o mananın halifeliğini yerine getirebilme tarihidir. Çünkü insan yeryüzünde Allah'ın halifesidir. Bu sebeple insan Allah hakikatini ve o kelime ile ifade edilen manayı tanımalı, bilmeli ve bu bilişe göre de yaşamalıdır. Tüm nebiler, resuller ve onların idrak ve yaşantılarının takipçileri, bu doğru varıık algısını inşa etmek veya onarmak misyonu ile gelip yaşamışlar, bunun için çaba harcamışlardır. Nebevi öğretide, "müstakilen varım ve muhtarım" iddiası olmayan "varlık" algısı ile hayat gerçek manasını kazanır ve alt ölçekte diğer tüm kavramlar yerli yerine oturur. Varlığın 
"müstakilen var ve muhtar" olmadığı idrakindeki insanlar, hayata ve yaşama alanlarına "mutlak sahiplik" anlayışıyla değil, bir "emanet" algısıyla bakar ve bu halleriyle varlığa ve yaşam alanlarına Allah adına halife olarak müdahale yetkisi kullanırlar [18]. Yeryüzünde yaşayan insanlar arasında ancak bu algıdaki bireyler mülk ve mülkiyet kavramlarının manalarını doğru tanımlayabilir ve doğru davranışlarda bulunabilirler. Mal, mülk ve mülkiyet kavramlarını bu şemsiye altında tanımlayamayan insan, kendi varlığını yani benliğini "müstakil ve muhtar" sandığında gerçek varlık algısından uzaklaşmakta, bu konudaki düalite türevlerine düşmektedir. Bu algıdaki insan, gerçek varlık ve benlik algısının düalitesinin sonuçları olan kapitalizm, komünizm, sosyalizm, faşizm gibi felsefelerle hakça paylaşımı ve mutluluğu bulmaya çalışmış, ancak hedefine kesinlikle ulaşamamıştır. Beşerî sistemlerin yanlış varlık algıları, mülkiyete yanlış bir yaklaşım getirmiş ve yine mülkiyet olgusu üzerinden adaletsizliklerin oluşmasinda da temel neden olmuştur. Bu sebeple bozulan adalet ve işleyiş, dünyayı ve hayatı bir savaş alanına dönüştüren anlayışlara, felsefe ve olaylara fırsat ve imkân oluşturmuştur.

Insan kendisi dâhil tüm yaratılmışlardaki canın/hissetmenin Allah'a ait olan ve kendilerine emaneten verilmiş "hissetme" vasfı olduğunu ve dünya hayatının bu paydaşlıkla devam ettiğini unutmadığında, yerleşim alanları, ülkeler ve medeniyetler gerçek manada imar edilebilir. Bu haldeki insan, algl yanılmasına (nisyana) düşmeden, mülke, güce ve hükme sahip çıkmadan müdahalelerini Allah adına, o'nun halifesi olarak gerçekleştirir. Ancak bu anlayıştaki insan şehir, bölge, ülke gibi her ölçekteki yerleşim alanlarına dokunuşlarında o mekândaki her hak sahibini göz önünde bulundurmak, haklarını vermek çabası içinde olur ki bu mülke adil yaklaşımda ilk ilkedir. Burada da karşımıza eşitlik ve adalet olarak iki kavram çıkmaktadır. Eşit kelimesi yapı, değer, boyut, nicelik ve nitelik bakımından birbirinden artık ve eksik olmayan iki veya daha çok şey anlamında olup, dilimize 19. yy. ortalarında girmiştir (TDK) [54]. Bu anlamı ifadede kullandığımız kadim kavram müsavat kelimesidir [3]. Müsavat "ölçü ve değer bakımından eşit olma, iki şey arasındaki denklik" anlamına gelir. Râgıb el-ísfahani müsavatın bir şeyin ücretsel değerini ifade etmede kullanıldığını, değerdeki eşitlik manasından geldiğini belirtmektedir (TDV). Bu tanımlara ontolojik olarak bakıldığında eşitlik/müsavat, iki ya da daha çok nesnenin aynı olmasını değil çeşitli özellikler yönünden birbiriyle denk olma durumunu göstermektedir. Ontolojik anlamda iki şeyin aynı olması zaten düşünülemez. Çünkü iki şey birbirine ne kadar benzer olsa da iki şey oldukları sürece aynı değildirler. Dolayısıyla, evrende, evrensel işleyişte mutlak eşitlik söz konusu olmamakla beraber iki ya da daha çok nesnenin çeşitıi sıfatları açısından eşitliği söz konusu olabilmektedir [25].

Genel olarak, her sahada tam eşitliği savunanlar, eşitliğin adaleti temin ettiği inancındadırlar. Eşitlik-müsavat, Allah'ın insanları yargılamada göz önünde bulundurduğu ahlaki bir ölçüsü olmakla beraber, varlık mertebelerinden kaynaklanan farklılıklardan dolayı Kur'ân'da, eşitlik değil de "hak" ve "adalet" kavramları öne çıkar. Bu durumda adalet, varlık mertebelerinden kaynaklanan toplumsal ve bireysel farklılıkları da göz önünde bulundurarak hakların karşılığının teslim edilmesidir, hak edene hak ettiğinin verilmesidir. Eşitlik ise bu prensibin herkese aynı uygulanmasıdır. Sürdürülebilir bir toplumda temel amaç adaleti gerçekleştirmektir. Eşitlemek hedefi adaletin gerçekleştirilmesinde önemli bir yere sahiptir fakat yanlış bir eşitlik anlayışı tam bir eşitsizliği de ortaya çıkarabilir [25] . Bu anlamda adalet realitedir ve sürdürülebilir bir manaya sahiptir. Çünkü eşitliği göz önünde bulundurduğu kadar, varlık mertebelerinden 
kaynaklanan toplumsal ve bireysel farklılıkları da göz önünde bulunduran bir manadır. İslam dini açısından fertler arasındaki iktisadi güç farklılaşması ve derecelenmesi, iktisadi faaliyetlerin canlılığı için toplumsal bir gerçekliktir. Yine gelir ve kabiliyet farklılaşmasının, insanların iş bölümü için olduğu belirtilmiştir (Nahl, 16/71, Zuhruf, 43/32). Bu anlamda iş bölümü ve iktisadi güç farklılaşması ve derecelenmeleri, İslam cemiyetinde Batı'daki anlamıyla keskin sınıflaşmalara yol açmamıştır. Ana sebep, İslam'ın topluma ve sosyal adalete ilişkin hükümleridir denilebilir.

Adalet kelimesinin kökenine baktığımızda davranışta ve hükümde doğru olmak, hakka göre hüküm vermek düzen, denge, denklik, eşitlik, gerçeğe uygun hükmetme, doğru yolu izleme, adil olmak gibi anlamlara geldiği ve "denk oldu, ölçülü oldu" anlamına gelen "adale" fiilinden türediği görülmektedir. Kökenine baktığımızda adalet kavramında bir tartma, bir karşılaştırmanın olduğu, birden fazla kriteri tartmak, dengelemek gerektiği görülür (TDV). Buradan hareketle toplumun dengesi adalet kavramıyla açıklanabilir ve İslam ekonomisinin topluma ilişkin hükümleri sosyal adalet olarak ifade edilebilir. Sosyal adaletin sağlayıcısı ve koruyucusu devlettir, devletlerin sürdürülebilirliğinin göstergesi de adalettir. Bu sebeple, "Adalet Mülkün temelidir" ilkesi evrenseldir, olmazsa olmazdır, bir söylem olarak kalmamalıdır. Bu anlamda sürdürülebilir bir devlet yönetimi için önem arz eden mülkiyet ve ekonomi, yani gelir sağlama ve gelir gider dengeleme süreci adalete dayanmalıdır. Bu yüzden, âdil gelir dağılımı mülkiyetin paylaşımı "(Servet) içinizden yalnız zenginler arasında dolaşan bir devlet olmasın" düsturuyla iktisat siyasetinin bir esası olarak belirtilmiştir [43]. Bunun için yönetim politikalarının çok dikkatli ve uzun vadede bu ilkeleri mutlaka sağlayacak şekilde oluşturulması gerekmektedir. İslam anlayışında biyolojik ve maddî farklılıklar, iktisadi ve siyasi derecelenmeler üstünlük gerekçesi değildir.

Kişinin üstünlüğünü belirleyen şey, şahsiyet kazanma mücadelesinde ileri bir merhale olan takva (Hucûrât, 49/13) ve ilimdir (Zümer, 39/9). İslam toplumlarında seküler anlayışlar güç kazandıkça sınıflaşmaya doğru eğilimler ortaya çıkmakla beraber, sosyal sınıflar İslam toplumunda genel anlamda aşırı sosyal yarılmalarla toplumun daimî bir sorunu olmamıştır. Toplumumuzda Osmanlılarda da gördüğümüz gibi, sosyal refah kavramı ön plandadır. Ekonomik faaliyetlerin belli bir sınıfın öncülüğüne değil, toplumun geneline yayılmasına çalışılmıştır. Bu anlamda önceleri küçük işletmeciler korunmuş ve sosyal ve sınıfsal ayrılmalar arasında uçurumlar oluşmamıştır. Devletin varlık hikmeti, sosyal adaletin gerçekleştirilmesidir ki esasları; israfın bertaraf edilmesi, âdil gelir bölüşümü ile servet ve mülkiyetin yaygınlaştırılması, iktisadi bağımsızlığın sağlanması ve iktisadi istikrardır. İslam'daki servet ve mülkiyetin yaygınlaşması ayeti kapsamındaki anlayış belirli kişilerin, grupların, şehirlerin ve bölgelerin ezici çoğunluğuyla gerçekleşecek bir adalet ve kalkınma kavramına zıttır. İşte burada sermayenin, fakirliğin ya da işsizlik örneğindeki çeşitli değerlerin belirli şehirlerde ve bölgelerde toplanmamasının gözetilmesi mekânsal adalet olarak karşımıza çıkmaktadır. Mekânsal adalet kavramının geçmişine baktığımızda, insanlık tarihi boyunca tüm din ve felsefelerde üzerinde en çok durulan kavramlardan birinin adalet olduğu görülmektedir. Felsefede ilk sistemli adalet tanımının Aristoteles ile başladığı söylenebilir. Aristoteles'in adalet tanımı sonrasında Farabi, İbn Miskeveyh, Ragıp El İsfahani gibi düşünürler tarafından tekrar tekrar ele alınmıştır [45]. Adaletle ilgili çağdaş tartışmalar halen devam etmekle beraber, adaletin dağıtımı konusu yakın dönemde John Rawls tarafından tartışmaya açılmıştır [36]. Adaletin kentsel [31 ve 42], çevresel [22 ve 24] ya da sosyal dağılımı [34], etiği [26 ve 41], politikaları [6, 
13 ve 14] ile ilgili birçok çalışmalar yapılmış, ama adaletin konum bazlı dağılımının "mekânsal adalet/spatial justice" adı ile adlandırılması ve literatüre kazandırılması ilk defa Güney Afrikalı Coğrafyacı Gordon Pirie tarafından olmuştur [35]. Sonrasında şehir plancısı ve siyasi coğrafyacı Edward Soja "Seeking spatial Justice" adlı kitabında mekânsal adaleti, "sosyal olarak değer verilen kaynakların ve bunları kullanma fırsatlarının mekânda adil ve eşit dağılımı" olarak tanımlamıştır [40 ve 42]. Soja'ya göre mekânın, yaptığımız her şey üzerinde olumlu olduğu kadar olumsuz sonuçları da olasıdır. Mekânsal (iç) adalet hem bir sonuç hem de bir süreçtir. Mekânsal adaletsizliğin sonuçlarını belirlemek kolay olsa da mekânsal adaletsizliklere yol açan ve temel oluşturan süreçleri anlamak karmaşıktır. Bununla birlikte, eşitsizliklerin giderilmesi ve adalete hizmet edilmesi için bu kavram temel bir analiz noktasıdır [27 ve 37]. Bu anlamda soja'nın da işaret ettiği gibi her ölçekte sürdürülebilirlik, içte (enfüste, derinlikte, benlikte) ve dışta (afakta, fenomenlerde) adaletle, yani ekonomik, sosyal ve moral değerlerin dengesi ile mümkündür. Bunlardan herhangi birinde dengenin bozulması sürdürülebilirliğe sekte vurmaktadır. Bu anlamda Dünya'da doğal kaynakların, sosyal, kültürel ve ekonomik değerlerin kullanımı, tüketimi ve kirletilmesi anlamında adaletsizlikler ve problemler küresel olarak had safhaya ulaşmıştır. Birleşmiş Milletler Kalkınma Programı (UNDP), küresel büyüklüğe ulaşan bu problemlerle mücadele edebilmek ve doğa ve toplum arasındaki her boyuttaki ve türdeki ilişki ve etkileşimi gelecek nesillerin hakları gözetilerek sürdürülebilir kılmak için; yoksulluğun azaltılması, demokratik yönetişim, enerji, çevre, sosyal kalkınma, kriz önleme, gezegenimizi koruma ve insanların barış ve refah içinde yaşamasını sağlama amaçlı temel sorunları çözme adına 17 evrensel amacı gerçekleştirmeyi hedeflemiştir (Şekil 1 ).
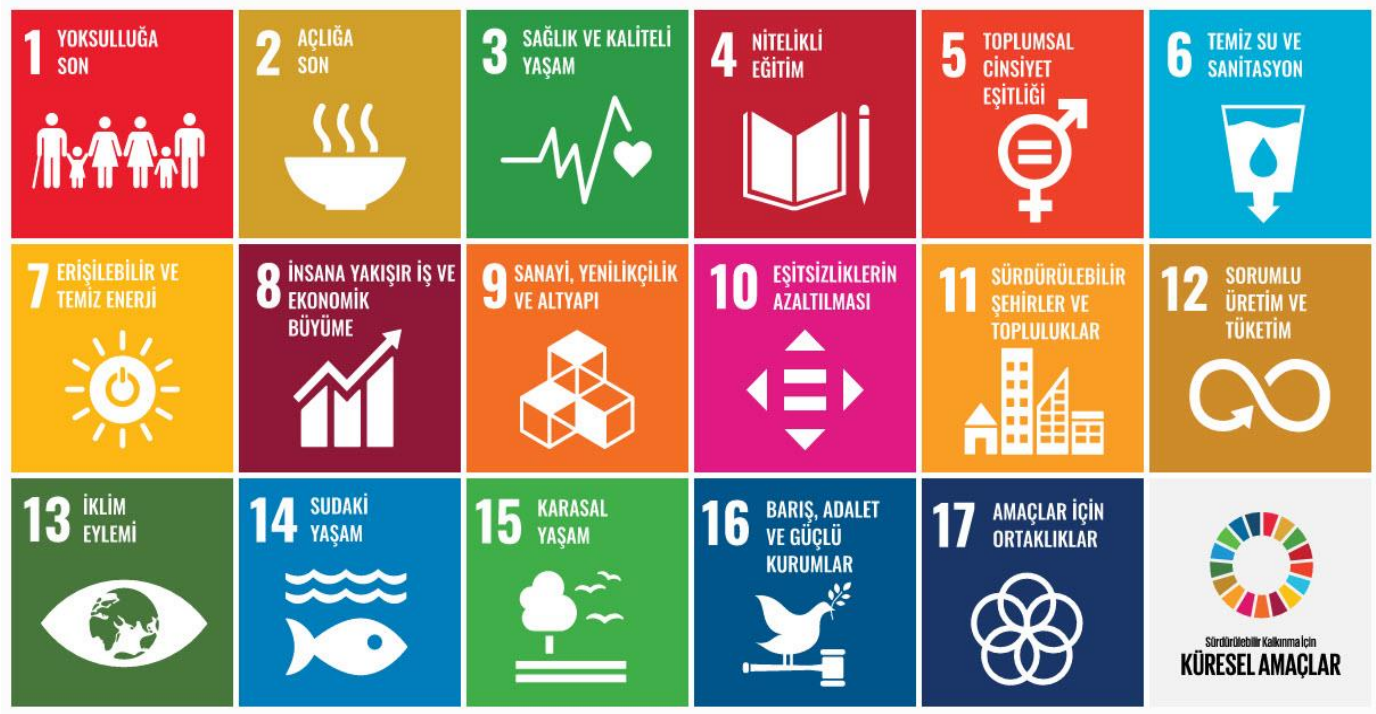

Şekil 1. Sürdürülebilir kalkınma amaçları

(Figure 1. Sustainable development goals)

Birbirinden ayrı gibi görülen bu 17 sürdürülebilir kalkınma amacını (SKA) bütüncül olarak incelediğimizde, (günümüz dünyasında nasıl herkesin hayatı bir diğeri ile bir şekilde bağlantılı ise) sürdürülebilir bir küresel kalkınmanın gerçekleştirilebilmesi için belirlenen amaçların bu anlamda birbiriyle bağlantılı olduğunu görmekteyiz. Çünkü günümüzde yoksulluk, iklim değişikliği, göç, işsizlik gibi sosyal veya ekonomik krizler artık tek bir ülke ya da bölgeye bağlı kalmamakta ve sınırları aşabilmektedir. Bölgesel ve 
ülkesel derin farklılıklar ve eşitsizlikler, uzun vadede toplumsal ve ekonomik kalkınmayı tehdit edebilmekte ve toplum ve çevrenin tahribine yol açmaktadır. Bu anlamda, SKA'lardan 10.'su ülkeler arasındaki ve ülkelerin kendi içindeki çok katmanlı adaletsizlikleri (eğitim, sağlık, gelir dağılımı, yoksulluk ve istihdam gibi) azaltmayı, güvenli, düzenli ve kurallı göçü sağlamayı, yaşa, cinsiyete, engelliliğe, ırka, etnik kökene, dine, ekonomik ya da başka bir statüye bakılmaksızın herkesin güçlendirilmesiyle beraber, uluslararası ekonomik ve finansal karar alma süreçlerinde gelişmekte olan ülkelerin sesini güçlendirmeyi amaçlamaktadır [49, 50 ve 51]. Yine mali, ücret ve sosyal koruma politikaları başta olmak üzere gerekli tüm politikaların benimsenmesi ve eşitliğin giderek daha çok sağlanması da SKA 10. maddesinin amaçları arasında yer almakladır.

BM Sürdürülebilir Kalkınma 2020 Raporu [39] incelendiğinde, Türkiye'nin 166 ülke arasında 70.3 endeks puanı ile 70. sırada yer aldığı görülmektedir. Türkiye'nin 17 hedefin gerçekleştirilmesi yönünde hızlı adımlar atması gerektiğine işaret eden raporda, yoksulluğun sona erdirilmesi konusunda Türkiye'nin bir ilerleme içinde olduğu kaydedilmekle beraber, en geride kaldığı amacın SKA 10 (eşitsizliklerin giderilmesi) olduğu belirtilmiştir. Bu husus yine Cumhurbaşkanlığı Strateji Daire Başkanlığınca yayımlanan değerlendirme raporunda da (2019) vurgulanmaktadır. SKA 10. açısından bakıldığında Türkiye'nin, 2000-2016 döneminde gelir dağılımının iyileştirilmesi ile mutlak ve göreli yoksulluğun azaltılması konularında uygulanan sosyal ve ekonomik politikalar sonucunda önemli ilerlemeler kaydettiği belirtilmektedir. Bununla beraber bu amaç kapsamında öne çıkan temel eksiklikler, bölgesel, sektörel ve kırılgan kesimler bazında eşitsizliklerin azaltılması, gelir dağılımın iyileştirilmesi ve fırsat eşitliğinin artırılmasıdır. Literatürde, farklı ülkelerdeki işsizlikleri [8, 10 ve 29], Avrupa Birliğinde işsizlikleri [38], boşanmaları [28 ve 48] gelir dağılımını [1 ve 4] inceleyen birçok çalışma vardır. Yine Türkiye'deki işsizlikleri [2 ve 11], gelir dağılımını [9, 15, 33 ve 47], boşanmaları [7 ve 12] irdeleyen il ya da bölge düzeyinde veriler kullanarak, analiz ve yorumlamalar da bulunan yayınlar mevcuttur. Literatürden farklı olarak bu çalışmada mahalle ölçeğinde veriler kullanılmıştır. Yine konunun tartışılmasında insan, mekan ve adalet kavramları birer fenomen olarak değil, evrensel gerçeklik ve evrensel genel doğrular ışı̆̆ında ve güncel terminoloji kullanılarak ele alınmıştır [16]. Bu anlamda makalede, SKA 10 kapsamında ülkemize tavsiye edilen bölgesel, sektörel ve kırılgan kesimler bazında eşitsizliklerin azaltılması ve gelir dağılımının iyileştirilmesi için geliştirilecek stratejileri, uygulamaya geçirilebilecek çalışmaları ortaya koyma adına ilk adım atılarak; sosyal ya da ekonomik indislerin mekânsal istatistiksel yöntemlerle nasıl irdelenip problemli yer ya da bölgelerin ortaya çıkarılabilmesi usulleri 3 farklı veri seti örneğinde ve postakodu5 coğrafi seviyesi ölçeğinde gerçekleştirilmiştir.

\section{METODOLOJI (METHODOLOGY)}

\subsection{Veri (Data)}

$\mathrm{BM}^{\prime}$ in SKA 10 (Eşitsizliklerin Azaltılması) hedeflerinde 10 alt hedef başlığı altında 11 gösterge bulunmaktadır. Bu anlamda eşitsizliklerin çok kriterli ve çok katmanlı oluşu ve kriterlerin bazıları hakkında ülkemizde veri toplanılmaması gibi hususlar, bu alanda tüm konuları kapsayacak bir çalışmayı tek bir makalede ortaya koymayı olanaksız kılmaktadır. Bu anlamda Türkiye için önerilen ve gerçekleştirilmesi şiddetle tavsiye edilen bölgesel, sektörel ve kırılgan kesimler bazında eşitsizliklerin azaltılması, gelir dağılımının iyileştirilmesi ve fırsat eşitliğinin artırılması hedefi 
adına; işsizlik, kişi başına gelir cinsinden satın alma paritesi (GDPPPP) ve boşanma sayıları indisleri örneğinde ülkemizin "mekânsal adaletsizlik" kavramı altında bir incelemesi yapılmıştır. Bu anlamda kullanılan sayısal veriler Esri Türkiye Demografik verileri (2020), Dünya Bankası ülkesel gösterge verileri, Birleşmiş Milletler Ekonomi Departmanı istatistiki verilerinin derlenmesi ile oluşturulmuştur. Sayısal verilerin kaynağı Türkiye İstatistik Kurumu tarafından 1988 yılından itibaren düzenli olarak uygulanmakta olan Hane Halkı İşgücü Anketi olup, ülkedeki işgücü piyasasının durumu ve sosyodemografik yapı hakkında bilgi veren temel veri kaynağıdır. Nüfus verisi olarak 2019 yıl ortası nüfus sayıları, işsizlik verileri olarak Tüik tanımıyla 2018 yılı işsiz sayıları, boşanma verisi olarak da 2019 yılı boşanma sayıları kullanılmıştır. Kişi başına gelir cinsinden satın alma paritesi olarak Dünya Bankası tarafından hesaplanan 2019 yılına ait satın alma gücü paritesi bazında kişi başı milli gelir (TL) rakamı kullanılmıştır. Satın alma gücü paritesine göre kişi başı gelir, ülkeler arasındaki fiyat farklılıklarını gidermek ve uluslararası alanda farklı para birimlerinin satın alma güçlerini karşılaştırabilmek için kullanılmaktadır. Kullanılan verilerde farklı kaynak ve ülkelerden gelen bölgesel verileri eşitleyebilmek için Dünya bankası ve BM İstatistik departmanı, bölgesel ham verileri ulusal istatistik ofislerindeki araştırmalara dayalı olarak (ILO) ayarladığını belirtmiştir [52]. Verilerin özetlendiği coğrafi düzey olan postakodu5 düzeyi ilçe sınırı ile mahalle sınırları arasında kalan bir coğrafi sınır ölçeğidir. Büyükşehir il merkezlerinde mahalle sınır düzeyine kadar inebilmekte, ilçe sınırları içerisinde ise ilçe sınırının yarısı veya daha az bir alanı kapsayabilmektedir [30].

\subsection{Metotlar (Methods)}

Haritalar, renk, grafik ve tasarımlarıyla kitlelerle iletişim kurarak bir şey anlatmak, bir fikir vermek için etkin iletişim araçlardır. Haritaların iletişim araçları olarak kullanımı, yazılı ve sözlü iletişimden bile eskilere dayanmaktadır. Zamanla kartografya ve bilgisayar teknolojilerinin gelişmesi ile haritaların iletişim aracı olarak etkileme gücü ve performansı da oldukça artmıştır. Haritalar, sağlık, ekonometri, suç, demografi vb. temaların dağılımını görselleştirmek [20], sebep ve sonuçlarını tahmin etme ve modellemenin yanında, potansiyel olarak yüksek riskli alanları belirlemek ve ilgilenilen konu için hipotezleri formüle etmek ve doğrulamak için etkili araçlardır [21 ve 29]. Haritaların görselleştirmedeki etkin performansı coğrafi bilgi sistemleri ve mekânsal analiz uygulamalarındaki kullanımını da artırmıştır. Günümüzde çeşitıi topluluklara ilişkin birçok demografik, sosyolojik, kriminolojik vb. veriler coğrafi, idari ya da politik sınırlar kullanılarak haritalarla ifade edilmektedir. Haritalar kullanılarak eyaletler, bölgeler, şehirler ya da daha alt ölçekteki geniş alanlardan gelen demografik, sosyoekonomik vb verilerdeki maskelenen üst ölçekteki değerler ortaya çıkarılabilmektedir [5 ve 20]. Bu anlamda mekansal eşitsizlik kavramı ışığında tüm dünyadaki işsizlik oranlarını ve dolar bazında GDP PPP gelir dağılımını anlayabilmek için koroplet haritaları oluşturulmuştur. Haritalar verilerdeki farklıların anlaşılabilirliğini artırmak üzere standart sapma sınıf aralıklarıyla sınıflandırılmıştır. Bu sınıflandırma türü öznitelik veri grubunun ortalama ve standart sapma değerlerini hesaplayıp sınıf aralık değerlerinin, ortalama değere standart sapma değerlerinin eklenip çıkartılmasıyla belirlendiği sınıflandırma türüdür. Öznitelik değerlerinin nerede yoğunlaşıp nerede seyrekleştiğini vurgulayan bir sınıflandırma metodudur [19]. 


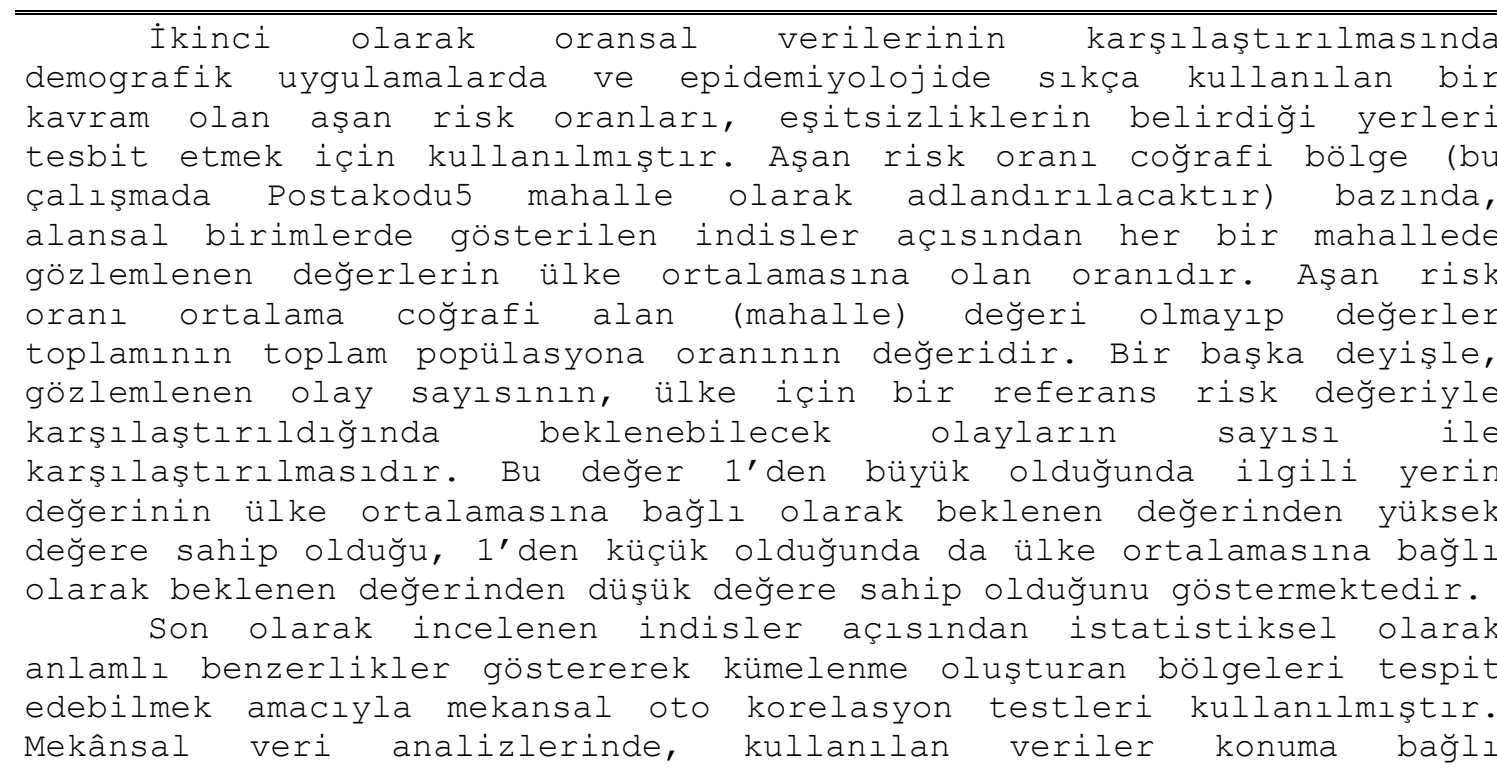
olduklarından hem öznitelik verilerindeki değişimi hem de alansal verilerin konumunun değişimini inceleyebilmektedirler. Mekânsal verideki öznitelik değerlerinin modellenmesinde kullanılan bir metot, bu öznitelik değerlerinin mekândaki değişimini açıklayamayabilir. Ya da bunun tersi durumlar söz konusu olabilir. Bu ise mekânsal analizleri, konuma dayalı olmayan matematiksel ve istatistiksel yöntemlerden farklı kılmaktadır. Mekânsal analizlerde kullanılan konuma bağlı veriler, istatistikte birçok uygulamada temel kabul edilen bağımsız örnekler kavramının aksine, seçilen gözlem değerlerinin konumlarına bağlı olarak sistematik bir ilişki ifade edebilmektedir. Bu durum mekânsal bağımlılık (spatial dependence) olarak tanımlanmakta olup, her şey her şeyle bağlıdır, bir şey her şeysiz yapılmaz. Bir şeyi halk eden, her şeyi halk etmiştir, gerçeğini "Her şey her şeyle ilişkilidir, yakın olan şeyler biraz daha fazla..." olarak isimlendiren Waldo Tobler tarafından Coğrafyanın 1. Kuralı olarak literatüre geçirilmiştir [44]. Bu anlayışta gerçek dünyada ölçülen, birbirlerine yakın mesafedeki veriler benzer özellikler gösterirken, aralarındaki uzaklık arttıkça bu benzerlik azalmaktadır. Mekânsal bağımlılığın ölçütü mekânsal otokorelasyon olup, mekânsal bir veri setinin öznitelik değerlerinin çalışma alanı içerisindeki dağılımında, sistematik bir örüntü-desen oluşturup oluşturmadığını gösteren sayısal bir ifadedir. Eğer konumsal verinin çalışma alanı içerisindeki dağılımı, yakın ya da komşu konumlardaki (lokasyonlardaki) verilerin öznitelik değerlerinin, uzaktakilere göre daha fazla benzer olması şeklinde ise, verilerde pozitif bir mekânsal otokorelasyonun olduğu ifade edilir. Tersi durum ise, yani yakın ya da komşu konumlardaki birbirine benzemeyen öznitelik değerlerine sahip objelerin dağılışı şeklinde ise negatif otokorelasyon olarak ifade edilir. Çalışma alanında konumu nedeniyle birbirleriyle etkileşim içinde olduğu düşünülen objeler arasında mekânsal bağımlılığın var olup olmadığının belirlenmesi yukarıda da belirtildiği üzere mekânsal otokorelasyonu ölçen testler ile gerçekleştirilmektedir.

Çalışmada coğrafi bölgeler (mahalleler) arasındaki mekânsal otokorelasyonu modellemek için farklı ağırlık matrisleri kullanılarak denemeler yapılmıştır. Alansal verilerde sıklıkla kullanılan mekânsal ağırlık matrisi, yakınlık ya da komşuluk matrisi olarak da adlandırılır. Bu ağırlıklar; grafik objeler arasındaki bağımlılığı, etkileşim, veya yayılmayı sayısal olarak tanımlarlar. Ağırlık matrisleri (W) çalışma alanındaki n sayıdaki grafik obje arasında, her bir objenin diğer objelerle ile ilişkisini göstermek üzere farklı 
kriterler kullanllarak oluşturulan $\mathrm{n} \times \mathrm{n}$ boyutlu matrislerdir ve analiz sonuçlarına direk etkisi olan en önemli unsurdurlar. Oluşturulan ağırlık matrisleriyle işsizlik, boşanma ve TL bazında satın alma paritesi cinsinden kişi başına gelir dağılımı değerlerinin mahalle bazında dağılımının anlaşılması için genel mekânsal otokorelasyon testleri kullanılmıştır. Bunlardan sık kullanılanlar Moran's I ve Geary c metotlarıdır. Moran'ın I indeksinin olası değerler aralığı -1 ile +1 arasında değişir. Pozitif değerler benzer değerlerin bir arada toplandığını (mekânsal kümelenme), negatif değerler ise farklı değerlerin bir arada (aykırı değerler) toplandığını gösterir. Geary c indisinin olası değer aralığı ise 0 ile 2 arasındadır. C'nin sıfır değerine yakın olması, benzer değerlerin bir arada toplandığını (mekansal kümelenme), c'nin değerinin 2'ye yakın olması ise farklı değerlerin bir arada toplandığını (aykırı noktalar) göstermektedir (Denklem 1 ve 2) [3].

$$
\begin{gathered}
I=\frac{N \sum_{i=1}^{N} \sum_{j=1}^{N} W_{i j}\left(X_{i}-\bar{X}\right)\left(X_{j}-\bar{X}\right)}{\left(\sum_{i \neq j}^{N} \sum_{j=1}^{N} W_{i j}\right)\left(\sum_{i=1}\left(X_{i}-\bar{X}\right)^{2}\right)} \\
c=\frac{(N-1) \sum_{i=1}^{N} \sum_{j=1}^{N} W_{i j}\left(X_{i}-X_{j}\right)^{2}}{2 \sum_{i=1}^{N} \sum_{j=1}^{N} W_{i j} \sum_{i=1}^{N}\left(X_{i}-\bar{X}\right)^{2}}
\end{gathered}
$$

Moran I ve Geary c indisleri birbirine benzer ya da farklı değerlerin bir arada konumlandığını göstermekle beraberler bu değerlerin yüksek ya da düşük değerler olduğunu ayırt edemez. Yüksek değerlerin bir arada toplanıp toplanmadığının (hotspot) tespitinde Getis-ord G indisi kullanılmaktadır [23]. G değeri beklenen değerinden büyükse yüksek değerlerin kümelenmediği, tersi durum ise düşük değerlerin kümelendiği anlamına gelmektedir (Denklem 3) [32].

$$
G(g)=\frac{\sum_{i} \sum_{j} w_{i j}\left(X_{i} X_{j}\right)}{\sum_{i} \sum_{j}\left(X_{i} X_{j}\right)}
$$

$\mathrm{Bu}$ indis değerleri ilgilenilen verinin dağılımını tek bir değerle işaret ederek genel dağılım hakkında bilgi verirken, genel dağılımın altında lokal olarak bulunabilen kümelenme ya da başka dağılım durumlarının tespiti için, yine aynı metotıarın ağırlık matrisleri ile her bir coğrafi alana (mahalle) ayrı ayrı uygulanmasıyla elde edilen değerleri kullanılmıştır. İncelenen değişkenlerin etkileşimlerini anlamak amacıyla aynı konumdaki (mahalledeki) iki değişkeni birlikte göz önünde bulundurarak mekansal oto korelasyonu ölçen bivariate lokal Moran's I indis değerleri de hesaplanmıştır (Denklem 4).

$$
I_{K L}=\frac{Z_{k} W Z_{i}}{n} \quad Z_{K}=\frac{x_{k}-\bar{x}_{K}}{\sigma_{K}} \quad Z_{i}=\frac{x_{i}-\bar{x}_{i}}{\sigma_{i}}
$$

Burada $n$ coğrafi ünite sayısı $Z$ değerleri de ortalama ve standart sapma ile standardize edilmiş değerleri göstermektedir.

\section{SONUÇLAR (RESULTS)}

Gelir eşitsizliği ve işsizlik küreselleşen dünyamız için artık ortak bir sorundur. 2018 Dünya Eşitlik Raporu'na göre, dünyada en üst 
ol'lik kesiminin küresel gelirden aldığı pay 1980 yılında ㄴ. 6 iken 2015 yllında \%22 olmuştur. En alt \%50'lik kesimin payl ise 1980 yılında $\frac{8}{8}$ iken 2015 yılında $\% 10$ olmuştur. 2020 Dünya verilerine baktığımızda en zengin olo'luk kitlenin, toplam küresel gelirin 40'ını elde ettiği, en yoksul olo'luk dilimin ise, küresel gelirden yalnız $\% 2$ ila 7 arasında pay aldığı tespit edilmiştir (UNDP, 2020). Dünyadaki eşitsizlik bölgeden bölgeye göre ciddi farklılıklar da göstermektedir. 2016 yılında en üst o10'luk dilimin toplam ulusal gelirden aldığı pay Avrupa'da \%37, Çin'de \%41, Rusya'da \%46, ABD'de \%47, Afrika'da \%54, Ortadoğu'da \%61'tir. Eşitsizliklerin en düşük olduğu yerin Avrupa, en yüksek olduğu yerin ise Ortadoğu olduğu belirtilmektedir. Ülkemizi Avrupa ile birlikte değerlendirdiğimizde, 34 Avrupa ülkesi içinde gelir dağılımı eşitsizliği sıralamasında Türkiye ikinci sırada yer almaktadır (Dünya Eşitsizlik Raporu, 2018).

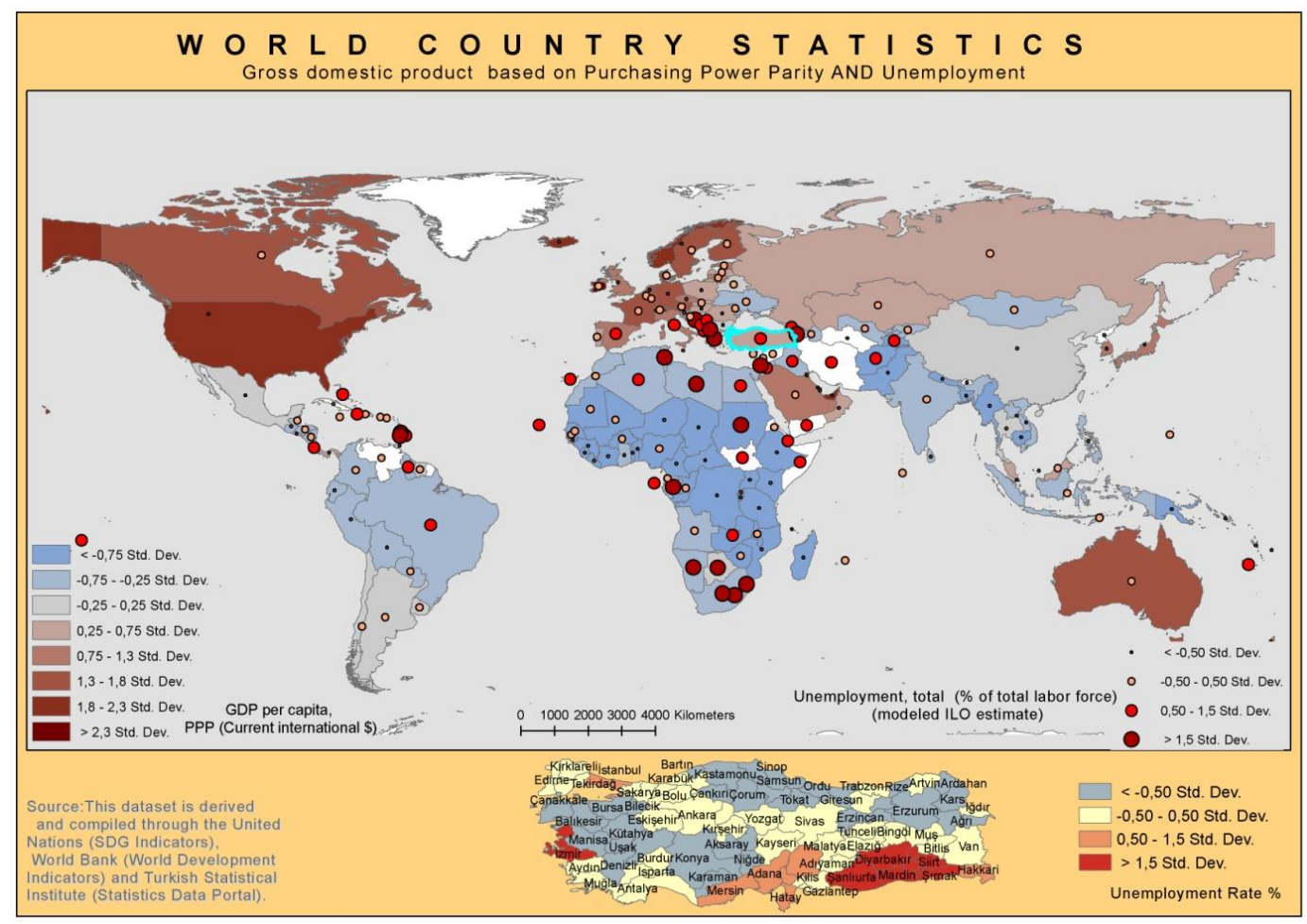

Şekil 2. İssizlik oranları ve USD bazında satın alma paritesi cinsinden kişi başına gelir dağılımı

(Figure 2. Unemployment rates and per capita income distribution in terms of purchasing parity in dollars)

Gini katsayısına baktığımızda Türkiye'de Gini katsayısı 2018 yılında 0.408 iken 2019'da 0.013 azalarak 0.395 olmuştur. Yani bir önceki yıla göre gelir dağılımı eşitsizliğinde azalma yaşandığı görülmektedir. Makalede incelediğimiz işsizlik ve GDP PPP değerleri açısından dünya ülkelerine ve ülkemizin durumuna baktığımızda (Şekil 2) dünya ülkeleri 2019 GDP PPP verileri standart sapma sınıf aralığı ile sınıflandırıldığında ülkemiz, Rusya, Kazakistan, Romanya, Yunanistan, Macaristan, Slovakya, Portekiz ve Polonya ile ayn grupta yer almaktadır. Orta Afrika ülkelerinin ise en kötü dilimde olduğu görülmektedir. 2018 yılı işsizlik verileri açısından baktığımızda ülkemiz Avrupa'da İtalya, İspanya ve Sırbistan'la aynı kategoride yer almaktadır. Haritalar kullanılarak geniş alanlardan gelen demografik, sosyoekonomik veriler görselleştirilmek suretiyle kullanıcılara etkin bilgi aktarımı sağlanabilmektedir. Bu veriler ülke, il ve ilçe gibi 
sınırlar içinde bütünleştirilerek gösterime sunulmaktadır. Bu anlamda bu tarz verilerin bütünleştirildiği idari sınırlar ne kadar büyük ölçekte ise altta yerel düzeydeki verilerin maskelenmesi, örtülmesi ve kaybolması da o kadar çok olabilmektedir. Bunun yanında, bu tarz verileri görselleştirmede kullanılan alansal sınırlar, ekolojik sınırlar olmayıp, geniş alanları kapsayan ve idarenin ihtiyaçlarına göre şekillenen ve bu ihtiyaçlara göre değiştirilebilen idari sınırlardır. Bu nedenle, alan verilerinin sınırları değiştiğinde, buna bağlı olarak komşuluk ilişkileri ve yakınlık-uzaklık ilişkileri de değişeceğinden sonuçların farklılaşabilmesine ve yanlış yorumlamalara sebep olan değişebilir alan sınırı problemi söz konusu olabilecektir. Çalışmada coğrafi düzey olarak mahalle verilerinin kullanılmasıyla bu sorunlar minimize edilmiş, il ya da ilçe sınırlarının maskelediği durumlar ortadan kaldırılmıştır. Bu anlamda boşanma, işsizlik ve GDP PPP değerlerinin dağılımı açısından ülke profiline baktığımızda, işsizlik oranlarının büyükşehirlerde, İç Anadolu ve Güneydoğu Anadolu bölgelerinde fazlalaştığı görülmektedir. GDP PPP değerlerinin dağılımına baktığımızda İstanbul, İzmir, Ankara, Bursa, İzmit ve Antalya dışında neredeyse tüm ülke değerlerinin düşük olduğu görülmektedir. Yine boşanma değerlerine baktığımızda batı kıyılarındaki fazlalık net bir biçimde görülmektedir. Doğu ve Güneydoğudaki büyükşehirlerin dışında hemen hemen tüm büyükşehirlerde boşanma değerlerindeki artış yine göze çarpan başka bir husustur. Bunların dışında Tunceli ve ilçeleri, Emirdağ (Afyonkarahisar), Kulu (Konya), Sinop ve ilçeleri ve Uşak yüksek değerlerle dikkat çekmektedir (Şekil 3). 


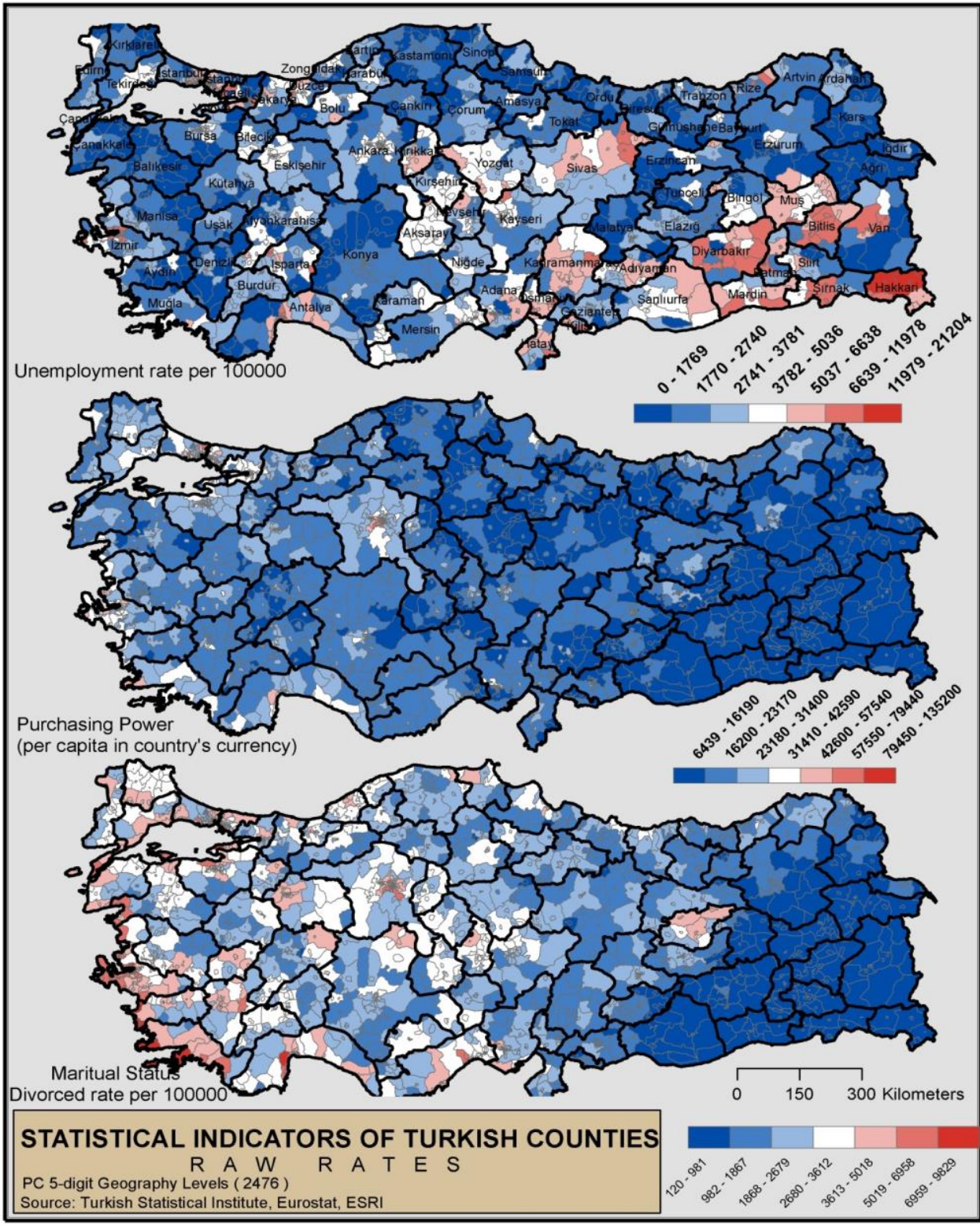

Şekil 3. İşizlik, boşanma ve TL bazında satın alma paritesi cinsinden kişi başına gelir dağılımı haritası

(Figure 3. Map of per capita income distribution in terms of unemployment, divorce and purchasing parity in dollar terms)

Aşan risk oranı değerlerine bakıldığında, aşan risk değerleri ülke için belirlenen referans değeriyle, bulunulan konumun değerini standardize ederek karşılaştırmamıza olanak sağlamaktadır. Şekil 4'e bakıldığında incelenen değerlerin 1'in üst ve alt katları cinsinden sınıflandırıldığı görülmektedir. Ortalama değer 1 değeri olup bu değerden farklılıklar oransal olarak ifadedir. İşsizlik oranlarının Güneydoğu Anadolu bölgesinde özellikle Hakkâri, Bitlis, Diyarbakır il ve ilçelerinde yoğunlaştığını görmekteyiz. Yine iç Anadolu'da Maraş, Sivas ve ilçeleri ile, bunlara ilaveten büyükşehirlerdeki yüksek oranlar da dikkat çekmektedir. İşsizlik oranları açısından baktığımızda en yüksek işsizlik oranına sahip Hakkari ile en az issizlik oranına sahip Derince (Kocaeli) arasında 130 kat farklılık olduğu görülmektedir. GDP PPP değerlerinin dağılımına baktığımızda İstanbul, İzmir, Ankara, Bursa, İzit ve Antalya merkez mahalleleri 
dışında neredeyse tüm mahalle değerlerinin düşük oranlara sahip olduğu görülmektedir. GDP PPP dağılımı açısından baktığımızda en yüksek GDP PPP oranına sahip Beyoğlu (İstanbul) ile en az GDP PPP oranına sahip Şirvan (Siirt) arasında 21 kat farklılık olduğu görülmektedir. Yine GDP PPP dağılımı için ayrıntılı istatistiki değerler, histogram grafiği, dağılımı daha detaylı gösteren voronoi haritası ve ortalama değerden daha yüksek GDP PPP değerlerine sahip mahalle konumları Şekil 5'de gösterilmektedir. Buna göre ülkenin en üst ol'lik kesiminin toplam gelirden (GDP PPP cinsinden) aldığı pay 2019 yılında \%17 olmuştur. En alt \%10'lik kesimin payı ise \%4 iken en üst \%10'luk kesimin payı ise \%23 olmuştur. Boşanma değerlerine baktığımızda, en yüksek boşanma oranına sahip Konak (İzmir) ile en az boşanma oranına sahip Mutki (Bitlis) arasında 82 kat farklılık olduğu görülmektedir. Marmara bölgesi, Batı Karadeniz kıyıları, Ege ve Akdeniz kıyı şeridiyle beraber, Ordu, Tunceli, Zonguldak ve Konya'nın ilçelerinin yüksek oranları dikkat çekmektedir. Doğu ve Güneydoğu Anadolu'nun oranları da dikkat çekici biçimde düşüktür.

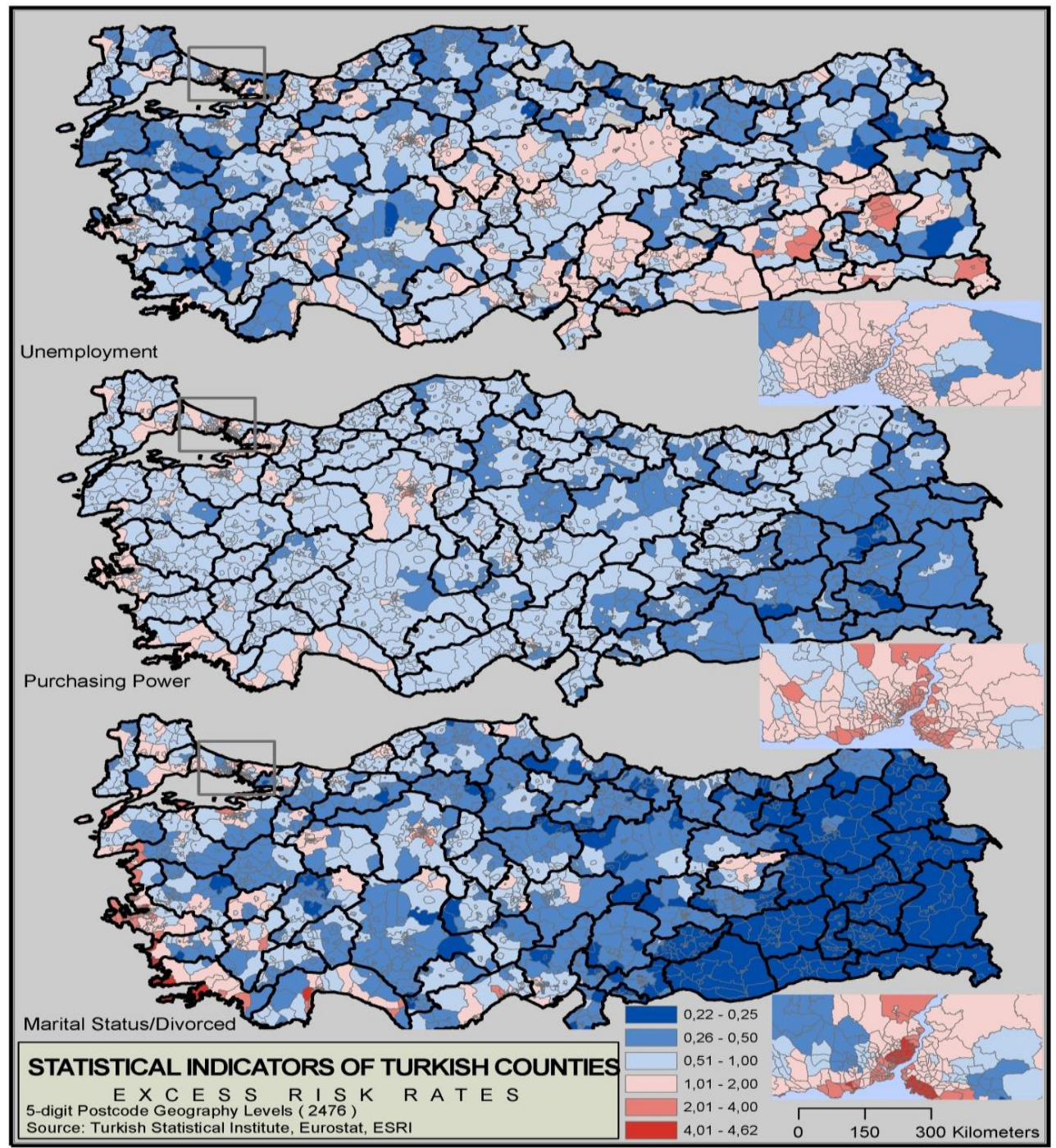

Şekil 4. İşizlik, boşanma ve TL bazında satın alma paritesi cinsinden kişi başına gelir dağılımı değerleri için aşan risk haritaları

(Figure 4. Excess risk maps for unemployment, divorce and per capita income (GDP PPP)) 


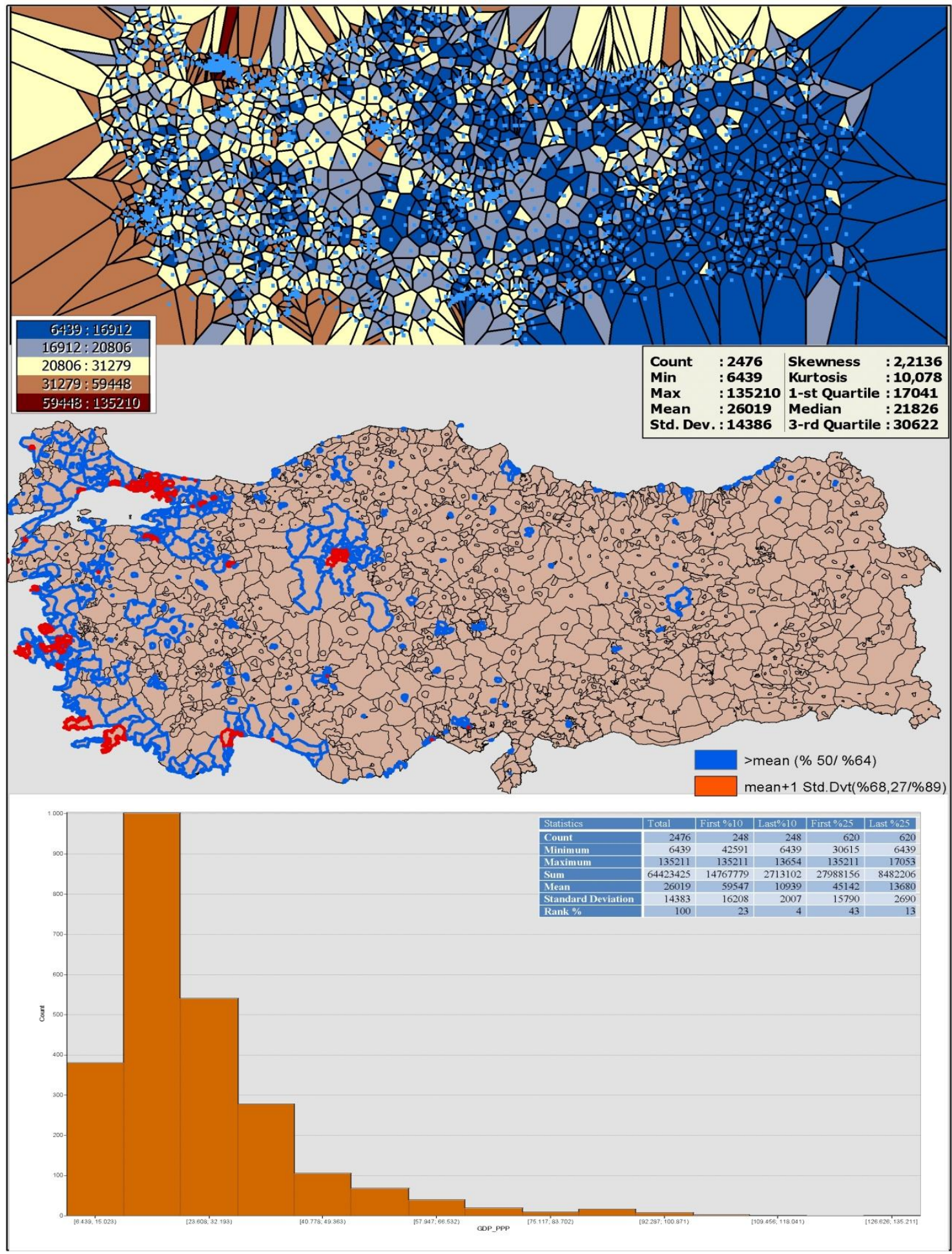

Şekil 5. Türk lirası bazında satın alma paritesi cinsinden kişi başına

gelir dağılımı değerleri voronoi haritası (en üstte), ortalamadan yüksek lokasyonlar haritası (ortada) ve histogram grafiği

(Figure 5. Voronoi map of per capita income in terms of purchasing parity in Turkish lira (top), Neighborhoods higher than average value (in the middle) and histogram chart (below)) 
İncelenen işsizlik, GDP PPP ve boşanma değerlerinin ülkemizdeki dağılımını belirleyen global mekansal otokorelasyon test sonuçlarına bakıldığında (Tablo 1), bütün metotların yüksek istatistiksel anlamlılık değerleriyle tüm değişkenlerde kümelenme karakteristiği tespit ettiği görülmektedir. Moran I indisi (Şekil 6) ve Getis-Od G (Şekil 7) ile belirlenen kümelenmelere baktığımızda küçük farklılıklar olmakla beraber her iki metotla da benzer tespitlerin olduğu görülmektedir.

Tablo 1. Global mekansal oto korelasyon test sonuçları

(Table 1. Global spatial autocorrelation results)

\begin{tabular}{|l|c|c|c|}
\hline Metot & İşsizlik & GDP PPP & Boşanma \\
\hline Moran I değeri (NN8) & 0.399 & 0.292 & 0.429 \\
\hline İstatistiksel Anlamlılık düzeyi & $>0.001$ & $>0.001$ & $>0.001$ \\
\hline Moran I değeri (Mesafenin Tersi) & 0.245 & 0.292 & 0.299 \\
\hline İstatistiksel Anlamlılık Düzeyi & $<0.005$ & $<0.005$ & $>0.001$ \\
\hline Geary c Değeri & 1.044 & 1.076 & 1.052 \\
\hline İstatistiksel Anlamlılık Düzeyi & $>0.01$ & $>0.001$ & $<0.05$ \\
\hline Getis-Ord G Değeri (Mesafenin Tersi) & 0.000005 & 0.000006 & 0.000001 \\
\hline İstatistiksel Anlamlılık Düzeyi & $>0.001$ & $>0.001$ & $>0.001$ \\
\hline
\end{tabular}

Güneydoğu Anadolu bölgesinde özellikle Şanlıurfa, Mardin, Hakkari, Bitlis, Diyarbakır il ve ilçeleri ile İstanbul, İzmir, Ankara ve Bursa'da bazı ilçelerinde istatistiksel olarak anlamlı $(\mathrm{p}<0.05)$ yüksek işsizlik değerleri kümelenmeleri tespit edilmiştir. Tersine olarak Karadeniz bölgesinin genelinde, Afyon, Isparta ve Konya çevresi ile Kuzey Ege'de istatistiksel anlamlı düşük işsizlik değerleri kümelenmeleri tespit edilmiştir. GDP PPP değerlerinin dağılımına baktığımızda işsizlikten farklı olarak Güneydoğu Anadolu bölgesi haricinde yüksek GDP PPP değerleri kümelenmeleri, işsizlik kümelenmeleriyle benzerlikler göstermektedir. Düşük GDP PPP değerleri kümelenmeleri Orta Karadeniz bölgesinde etkisini kaybetmiş görünmektedir. Boşanma değerlerinde ise Marmara bölgesi, Batı Karadeniz kıyıları, Ege ve Akdeniz kıyı şeridinde yer alan İzmir, Muğla, Aydın ilçeleri ile İstanbul, Ankara, Antalya, Bursa merkeze yakın yerleşim alanlarında istatistiksel olarak anlamlı yüksek boşanma değerleri kümelenmeleri tespit edilmiştir. Yine Doğu ve Güneydoğu Anadolu'da istatistiksel olarak anlamlı düşük boşanma oranları belirgin olmakla beraber, Gaziantep, Şanlıurfa ve Diyarbakır'da düşük değerlerin kümelenmesinde belirgin azalmalar da ayrıca dikkat çekicidir. 


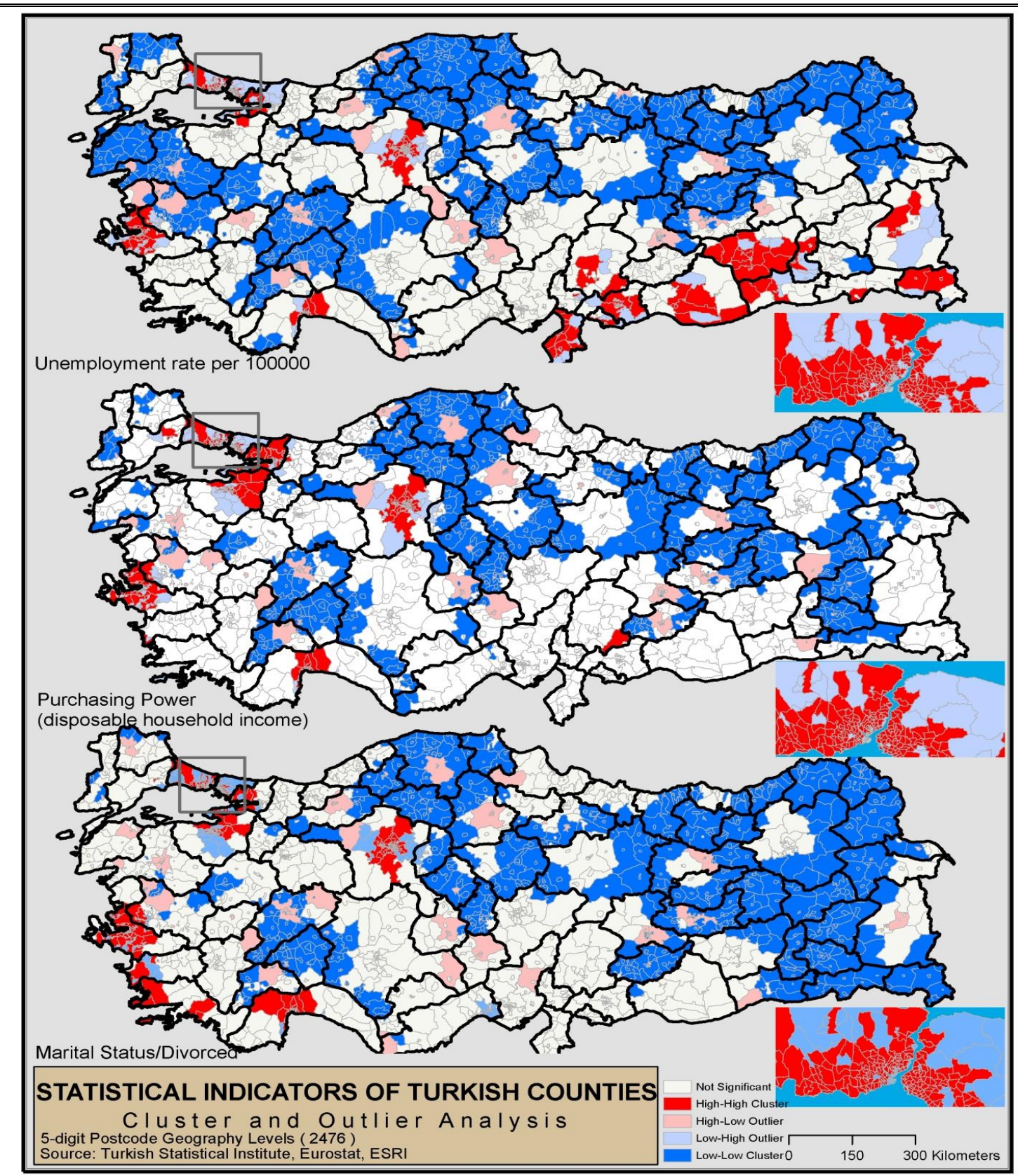

Şekil 6. İşsizlik, boşanma ve TL bazında satın alma paritesi cinsinden

kişi başına gelir dağılımı değerleri için kümeleme haritaları (Lokal Moran I)

(Figure 6. Clustering maps for unemployment, divorce and per capita income GDP PPP (Local Moran I)) 


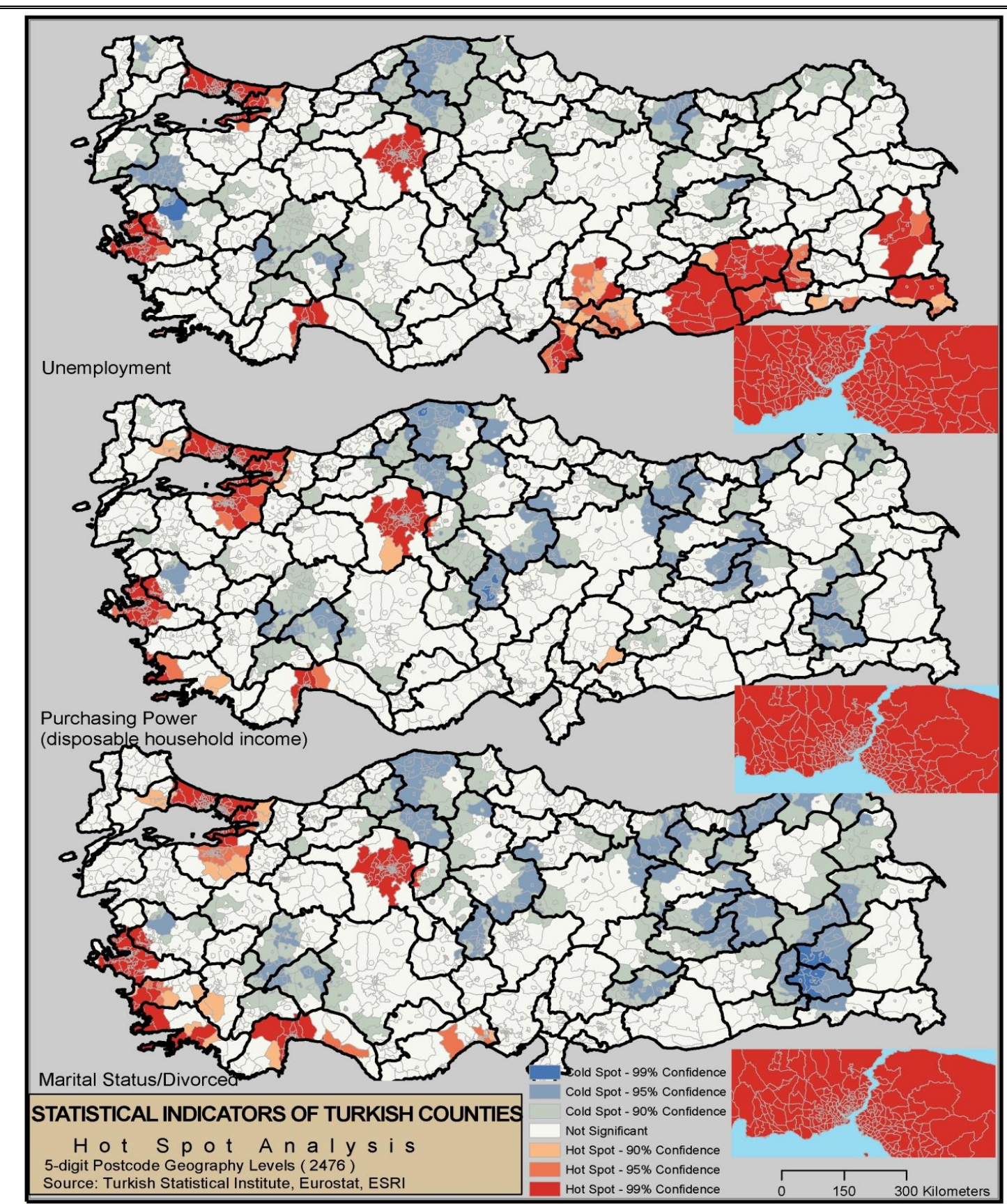

Şekil 7 İşsizlik, boşanma ve TL bazında satın alma paritesi cinsinden kişi başına gelir dağılımı değerleri için kümeleme haritaları (GetisOrd G)

(Figure 7. Clustering maps for unemployment, divorce and per capita income GDP PPP (Getis-Ord G))

İki değişkenin aynı konumdaki korelasyonunun, yani birlikte artış ve azalışını ya da bir değer artarken diğerinin azaldığını gösteren Bivariate Lokal Moran I haritaları incelendiğinde, işsizliğin yüksek olduğu yerlerde boşanmanın da yüksek olduğu anlamlı kümelenmelerin, İstanbul, Ankara, İzmir, Bursa, Antalya, Mersin, Gaziantep ve Antalya merkez bölgelerinde oldukları görülmektedir. Haritada morla gösterilen düşük işsizlik yüksek boşanma kümelenmeleri görülen yerlerden Denizli özellikle ilçeleriyle beraber dikkat çeken bir bölge olarak karşımıza çıkmaktadır. 


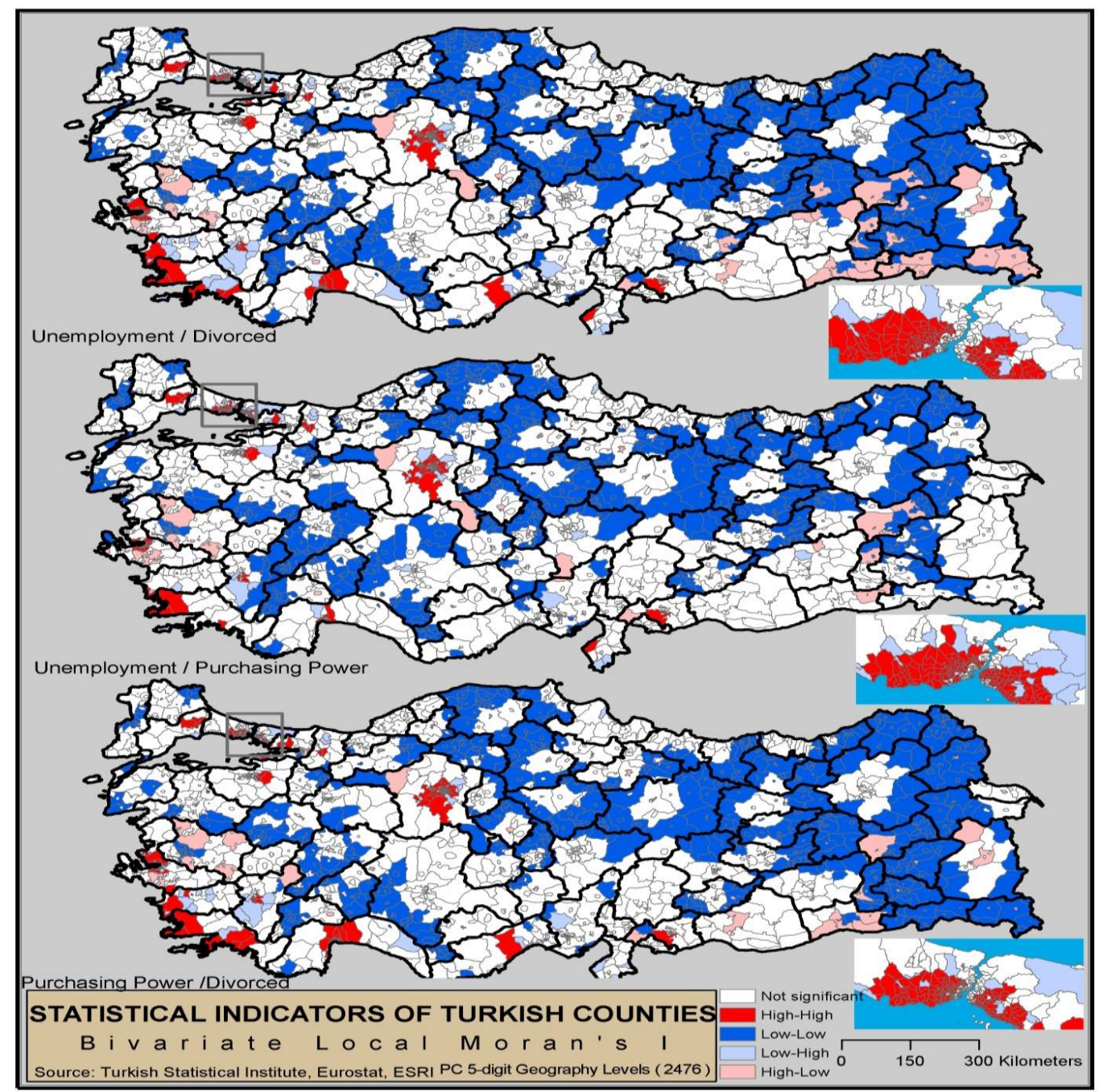

Şekil 8. İşsizlik, boşanma ve TL bazında satın alma paritesi cinsinden kişi başına gelir dağılımı değerleri için kümeleme haritaları (ìki değişkenli Lokal Moran I)

(Figure 8. Clustering maps for unemployment, divorce and income GDP PPP (Bivariate Local Moran I))

İşsizliğin yüksek olduğu yerlerde GDP PPP alım gücünün yüksek olduğu, anlamlı kümelenmelerin İstanbul ve Ankara ile sınırlı olmakla birlikte İzmir'in bazı bölgelerinde de görüldüğü tespit edilmiştir.

\section{TARTIŞMA VE ÖNERILER (DISCUSSION AND SUGGESTIONS)}

UNDP, sürdürülebilir kalkınmanın önündeki en büyük engelin ve çevre sorunlarının temelindeki en önemli olgunun "yoksulluk" olduğunu vurgulamaktadır. Bu kapsamda hayatın ve gelişimin sürdürülebilirliği için global olarak eşitsizliklerin giderilmesi, ekonomik büyümenin ve istihdamın insan ve çevre lehine güçlendirilmesi, yoksulluğun giderilmesi, insan onurunun korunması ve sürdürülebilir çevre öncelikli kalkınma politikalarından taviz verilmemesi, şehirler ve yaşama alanları ile topyekun habitatın iyileştirilmesi, iklim değişikliğiyle mücadele ve çevre-insan hakları-demokrasi üçlüsünün birbirini destekleyen döngüsünün güçlendirilmesi gibi hedefleri öngören 2030 ajandasında, 17 SKA kapsaminda toplam 169 hedef belirlemiştir. Ülkemizin de hedeflediği bu SKA'lar kapsamında SKA 10 (Eşitsizliklerin Azaltılması) hedefi için 2000-2016 döneminde, gelir 


\begin{abstract}
dağılımının iyileştirilmesi ile mutlak ve göreli yoksulluğun azaltılması konularında önemli ilerleme kaydedilmekle beraber, bölgesel ve sektörel bazda eşitsizliklerin azaltılması, gelir dağılımın iyileştirilmesi ve fırsat eşitliğinin artırılması konularında iyileşmenin sürdürülmesi ihtiyacının devam ettiği belirtilmiştir (TCCSBDB, 2019). Bu problemin anlaşılması ve ortaya konulması için gerçekleştirdiğimiz bu çalışmada, ülke nüfusunun homojen dağılmadığı, şehirlerde ve büyükşehirlerde özellikle İstanbul başta olmak üzere Ankara ve İmir'de anormal bir yığılma olduğu belki malumun ilamı olacaktır. Bununla beraber, bu nüfus yığılmalarının getirdiği sosyal, demografik ve ekonomik farklılaşmanın olumsuz etkilerinin henüz daha hissedilmeye başlanmadığı düşünülmektedir. Bunun nedeni olarak baktığımızda;
\end{abstract}

- Ülke profili, makalede ortaya konulan ve iç tutarlılık diyebileceğimiz mekansal adalet kavramı ışığında incelendiğinde, analizleri yapılan 3 farklı değişken örneğinde görüldüğü üzere; konuma bağlı olmayan istatistiki göstergelerin gerçek durumu yansıtmadığı gözlemlenmektedir. Başka bir deyişle söylemek gerekirse, istatistiki göstergelerin rakamsal değerlerinin mekansal dağılımı ile çekilen ülke fotoğrafından görüldüğü üzere, gerçek durumun genel istatistiksel değerler tarafından örtüldüğü anlaşılmaktadır.

- Sadece GDP PPP değişkeni üzerinden baktığımızda (Şekil 5), GDP PPP ortalama değerinin üzerindeki mahalle sayısının toplam mahallelerin $\circ 34^{\prime} \ddot{u}$, ortalamanın 1 standart sapma üzeri değerdeki mahalle sayısının toplam mahallelerin oll'i olduğu, bunların da büyük çoğunluğunun İstanbul (\%58), Ankara (\%14), İzmir (\%11) il merkezlerinde yer aldığı görülmektedir. Kalan o13'lük kısmın da Antalya, İzmit, Bursa ve Eskişehir il merkezlerinde konumlandığını görmekteyiz. Hem rakamsal anlamda hem mekânsal dağılım anlamında histogram ve mekansal otokorelasyon değerlerine göre normal dağılımdan büyük sapmalar olduğu ortadadır. GDP PPP dağılımının büyük şehirlerde toplanması, İstanbul için o58'lik, 3 büyük şehir için ise \%83 gibi bir oranın sadece 3 şehirdeki belirli mahallelerde kümelenmiş olması, kişi başı satın alma paritesi cinsinden gelir eşitsizliğini ortaya koyan rakamlardır.

- Bunun yanında yukarıda belirtilen 3 büyük şehirdeki mahallelerin işsizlik ve boşanma oranlarının istatistiksel olarak anlamlı yüksek kümelenme değerlerine sahip olmasının (yorumlanmasında ekolojik yanılmaya-ecological fallacy- düşmemek adına -saha çalışmalarında toplanan gelir, işsizlik ve boşanma değerleri aynı kişilerden derlenmediği için-) olası iki ana açıklaması söz konusudur. İlk yorum olarak "kişi başı satın alma paritesi cinsinden geliri yüksek yerlerde, kişilerde hem işsizlik hem de boşanma değerleri yüksektir" olarak yorumlarız ki mekânsal adaletsizliğin ekonomik ve sosyolojik olarak da beraberinde sorunlar getirdiğinin araştırılmasına ayrıca kapı açmaktayızdır. İkinci olarak, "kişi başı satın alma paritesi cinsinden geliri yüksek yerlerde yüksek işsizlik ve boşanma değerlerinin bir arada olduğu yani, bu şehirlerde ekonomik, toplumsal ve sosyolojik değerlerin ayrışmalarının ürkütücü biçimde beraber bulunduğu" yorumudur ki; ülke genelindeki farklılaşmanın çok üstünde bu şehirlerde toplumsal ve ekonomik farklılıkların ve yarılmaların olduğu sorununun araştırılmasına kapı açmaktadır. Görüldüğü üzere her iki yorum da mekânsal adaletsizlikle yüzleşmemiz gereğini ortaya koyan ülkemizin iki farklı fotoğrafıdır. 
- Çalışma, ülke çapında neredeyse mikro düzeyde diyebileceğimiz bir veri setinin kullanıldığı ilk araştırmadır. Sonuçlarla ilgili detaylı yorumlar çalışmanın hacmini çok fazla artıracağından kısa yorumlamalar ve genel çıkarımlarla yetinilmiştir. Bununla birlikte, bu ölçekteki verilerin yayınlanması bile önemli bir bilimsel platform oluşturmakta, yeni ve detaylı çalışmalara altıık olma potansiyeli taşımaktadır.

- Çalışma mekansal adalet kavramı ışığında Türkiye'deki işsizlik, satın alma gücü paritesi ve boşanma verileri üzerinden mekansal eşitsizliğinin doğasını incelemektedir. Makalede ortaya konulan bulgu ve çıkarımlar, akademisyenler, karar oluşturucular ve karar vericiler için eşitsizlikle mücadelede ihtiyaç duyacakları çalışmalar ve oluşturulacak politikalar için yol açıcı bir dayanak olabilir.

\section{NOT (NOTICE)}

Bu çalışma hakem aşamasında olan "Reducing Inequalities for Sustainable Development: A GIS Application for Spatial Justice in Turkey" makalesinin Türkçe genişletilmiş versiyonudur.

\section{ÇIKAR ÇATIŞMASI (CONFLICT OF INTEREST)}

Yazarlar çıkar çatışması bildirmemişlerdir.

\section{KAYNAKLAR (REFERENCES)}

[1] Annoni, P., De Dominicis, L., and Khabirpour, N., (2019). Location Matters: a Spatial Econometric Analysis of Regional Resilience in the European Union. Growth and Change: A Journal of Urban and Regional Policy, 50:824-855.

[2] Aral, N. ve Aytaç, M., (2018). Türkiye'de İşsizliğin Mekânsal Analizi. Öneri Dergisi, $13(49)$ :1-20.

[3] Anselin, L., (2019). A Local Indicator of M ultivariate Spatial A ssociation: Extending Geary's c. Geographical Analysis. $51: 133-150$.

[4] Armstrong, H.W., (1995). Convergence Among Regions of the European Union, 1950-1990. Papers in Regional Science, 74:143152 .

[5] Borrell, C., Marí-Dell'olmo, M., Serral, G., Martínez-Beneito, M., Gotsens, M., and others (2010). Inequalities in Mortality in Small Areas of Eleven Spanish Cities (The Multicenter MEDEA Project). Health Place, 16(4):703-11.

[6] Bradley, K. and Connelly, S., (2004). Spatial Justice, European Spatial Policy and the case of Polycentric Development. Paper Presented at the ECPR Workshop on 'European Spatial Politics or Spatial Policy for Europe?.

[7] Cafri, R. ve Özdemir Çukadar, P., (2018). Boşanmanın SosyoEkonomik Nedenleri Üzerine Mekânsal Ekonometrik Bir İnceleme. Uluslararası İktisadi ve İdari İncelemeler Dergisi, Prof. Dr. Harun TERZİ Özel Sayısı, 407-424.

[8] Cracolici, M.F., Cuffaro, M., and Nijkamp, P., (2009). A Spatial Analysis on Italian Unemployment Differences. Stat Methods Appl 18:275-291.

[9] Çapar, U. ve Yayla, N., (2019). Türkiye'de Bölgelerarası Gelir Dağılımı Yakınsaması: Mekansal Ekonometrik Analiz. Uluslararası İktisadi ve İdari İncelemeler Dergisi, (25):283-302.

[10] Cracolici, M.F., Cuffaro, M., and Nijkamp, P., (2009). A Spatial Analysis on Italian Unemployment Differences. Stat Methods Appl 18:275-291. 
[11] Çifçi, R., (2017). Spatial Structure of Unemployment in Turkey, Social Sciences Studies Journal, 3(10):1499-1507.

[12] Dereli, M.A. ve Polat, N., (2018). Boşanma Verilerinin Coğrafi Bilgi Sistemleri Destekli Mekânsal İstatistiksel Yöntemler ile İrdelenmesi, Harran Üniversitesi Mühendislik Dergisi, 3(3):112118 .

[13] Dikeç, M., (2009). Space, Politics and (in)justice/L'espace, Le Politique et l'injustice. Justice spatiale | Spatial Justice, No. 1, Septembre; Available at http://www.jssj.org

[14] Dikeç, M., (2005). Space, Politics, and the Political', Environment and Planning D: Society and Space, 23(2):171-188

[15] Doğan, T. and Kindap, A., (2019). Regional Economic Convergence and Spatial Spillovers in Turkey. International Econometric Review, $11(1): 1-23$.

[16] Dündar, Y., (2016). Sen Tanrı mısın, ISBN:978-605-88309-8-1.

[17] Erdoğan, S., Aslan, R., Ulukavak, M. ve Yılmaz, M., (2018). Evrilme ve Aklıyla Buluşma Açısından "Akılıı Şehirler" Kavramı: Şehirler Nasıl Akıllı Olur? Geotasarım Yaklaşımı, Kent Akademisi, Volume:11(33), Issue:2, Pages:264-273.

[18] Erdoğan, S. ve Aslan, R., (2019). Sürdürülebilir Şehirler İçin Tasarım Araçlarının Asıl Uygulayıcıları: Sivil Toplum ve Gönüllüler. Şehir ve Düşünce Dergisi, 13:106-117.

[19] Erdoğan, S., (2014). Editör, Bilgisayar Destekli Harita Yapımı ve Coğrafi Bilgi Sistemlerinin Temelleri, Uyum Ajans Ankara.

[20] Erdoğan, S., Yalçın, M., and Dereli, M.A., (2013). Exploratory Spatial Analysis of Crimes Against Property in Turkey, Crime Law Social Change, $59(1): 63-78$.

[21] Erdoğan, S., (2009). Explorative Spatial Analysis of Traffic Accident Statistics and Road Mortality Among The Provinces of Turkey. Journal of Safety Research, 40 (5):341-355.

[22] Fisher, J.B., Kelly, M., and Romm, J., (2006). Scales of Environmental Justice: Combining GIS and Spatial Analysis for Air Toxics in West Oakland, California. Health Place, $12(4): 701-14$.

[23] Getis, A. and Ord, J.K., (1992). The Analysis of Spatial Association by Use of Distance Statistics. Geographical Analysis, 24: 189-206.

[24] Goodman, K., (2017). Environmental Justice and GIS: A Comparison of Three GIS Methods for Estimating Vulnerable Population Exposed to Brownfield Pollution in Portland, Oregon". Geography Masters Research Papers. 19.

[25] Güler, İ., (1997). Kur'ân'da Kadın-Erkek Eşitsizliğinin Temelleri, İslâmî Araştırmalar, X(4):296-303.

[26] Harvey, D., (1973). Social Justice and the City (Edward Arnold, Maidenhead, Berks).

[27] Kang, S.Y., Cramb, S.M., White, N.M., Ball, S.J., and Mengersen, K.L., (2016). Making the Most of Spatial Information in Health: a Tutorial in Bayesian Disease Mapping for Areal Data. Geospat Health. May 31, $11(2): 428$.

[28] Su, L., Liang, C., Yang, X., and Liu, Y., (2018). Influence Factors Analysis of Provincial Divorce Rate spatial Distribution in China, Discrete Dynamics in Nature and Society, $2: 1-11$.

[29] Lopez-Bazo, E., del Barrio, T., and Artis, M., (2002). The Regional Distribution of Spanish Unemployment: A Spatial Analysis. Papers Reg Sci 81:365-389.

[30] Michael Bauer Research GmbH, (2019). Based on (C) Turkish Statistical Institute, Eurostat. 
[31] Mirgholami, M., Keynejad, M.A., and Alizadeh N.B., (2019). The Evaluation of Spatial Justice in Redevelopment of Urban Spaces; Case study: Atigh Local Plan in the City of Tabriz. Bagh-e Nazar, 15(67):43-52. https://doi.org/10.22034/BAGH.2018.80613

[32] Mitchell, A., (2005). The ESRI Guide to GIS Analysis, Volume 2: Spatial M easurements. California: ESRI press.

[33] Özmuçur, S. and Silber, J., (2002). Spatial Income Inequality in Turkey and the Impact of Internal Migration. Working Paper, Philadelphia: University of Pennsylvania.

[34] Denise, P., Velez, P., and Nelly, V., (2009). Maps, Mapmaking, and Critical Pedagogy: Exploring GIS and Maps as a Teaching Tool for Social Change," Seattle. Journal for Social Justice. $8(1): 11,273-302$.

[35] Pirie, G.H., (1983). On spatial Justice, Environment and Planning A 15:465-473.

[36] Rawls, J., (1971). A Theory of Justice Oxford University Press, London.

[37] Rigon, A., (2018). What is Spatial Justice? Course: Development and Planning in African Cities: Exploring Theories, Policies and Practices from Sierra Leone.

[38] Rios, V., (2016). What Drives Unemployment Disparities in European Regions? A Dynamic Spatial Panel Approach. Regional Studies, 11:1-13.

[39] Sachs, J., Schmidt-Traub, G., Kroll, C., Lafortune, G., Fuller, G., and Woelm, F., (2020). The Sustainable Development Goals and COVID-19. Sustainable Development Report 2020. Cambridge: Cambridge University Press.

[40] GHaedrahmati, S., Khademalhoosini, A., and Tahmasebi, F., (2018). Spatial Analysis of Social Justice in City of Isfahan, Iran, Annals of GIS, 24 (1):59-69.

[41] Smith, D.M., (1994). Geography and Social Justice, Oxford, Blackwell.

[42] Soja, E.W., (2010). Seeking Spatial Justice. University of Minnesota Press, Minneapolis.

[43] Tabakoğlu, A., (2017). İslam Toplumunda Sınıf Yoktur, Lacivert Sayı:40/Kasım 2017 .

[44] Tobler, W., (1970). A Computer Movie Simulating Urban Growth in the Detroit Region. Economic Geography, 46 (Supplement):234-240.

[45] Turan, R., (2017). X ve XI. Yüzyılda İslam Felsefesinde Yapılan Adâlet Taksimleri: Fārābī, Ebū'l-Hasan El-Āmirī, İbn Miskeveyh ve Rāg̣ıp El-İsfehānī Örneği. Namık Kemal Üniversitesi İlahiyat Fakültesi Dergisi (NKUIFD), $3(2): 91-115$.

[46] Türkiye Cumhuriyeti Cumhurbaşkanlığı Strateji ve Bütçe Dairesi Başkanlığı, (2019). Sürdürülebilir Kalkınma Amaçları Değerlendirme Raporu ISBN NO: 978-605-7751-13- Yayın No:0013.

[47] Yıldırım, J., Öcal, N. ve Özyıldırım, S., (2009). Income Inequality and Economic Convergence in Turkey: A Spatial Effect Analysis. International Regional Science Review, 32 (2) :221-254.

[48] Zaijun, L.I., Shuaibin, L.I.U., Zhifei, M.A., and Weixuan, S., (2017). Saptial Heterogeneity Analysis of Divorce Rate at the Provincial Level in China, J. Progress in Geography, $36(10): 1313-1320$.

[49] https://www.tr.undp.org. Erişim Tarihi: 10.08.2020.

[50] https://imece.com. Erişim Tarihi: 06.09.2020.

[51] https://www.kureselamaclar.org/. Erişim Tarihi: 12.10.2020.

[52] https://unstats.un.org/sdgs/metadata/files/Metadata-08-0502.pdf. Erişim Tarihi: 22.10.2020.

[53] https://tdv.org/tr-TR/. Erişim Tarihi: 23.11.2020.

[54] https://www.tdk.gov.tr/. Erişim Tarihi: 30.07.2020. 